\title{
EPIDEMIOLOGIA DA VASSOURA-DE-BRUXA (Crinipellis perniciosa (STAHEL) SINGER) EM CACAUEIROS ENXERTADOS EM URUÇUCA, BA
}

\author{
SILVIO ANDRÉ MEIRELLES ALVES
}

Dissertação apresentada à Escola Superior de Agricultura "Luiz de Queiroz", Universidade de São Paulo, para obtenção do título de Mestre em Agronomia, Área de Concentração: Fitopatologia.

\author{
PIRACICABA \\ Estado de São Paulo - Brasil
}

Dezembro - 2002 


\title{
EPIDEMIOLOGIA DA VASSOURA-DE-BRUXA (Crinipellis perniciosa (STAHEL) SINGER) EM CACAUEIROS ENXERTADOS EM URUÇUCA, BA
}

\section{SILVIO ANDRÉ MEIRELLES ALVES}

Engenheiro Agrônomo

Orientador: Prof. Dr. ARMANDO BERGAMIN FILHO

Dissertação apresentada à Escola Superior de Agricultura "Luiz de Queiroz", Universidade de São

Paulo, para obtenção do título de Mestre em Agronomia, Área de Concentração: Fitopatologia.

\author{
PIRACICABA \\ Estado de São Paulo - Brasil \\ Dezembro - 2002
}




\title{
Dados Internacionais de Catalogação na Publicação (CIP) DIVISÃO DE BIBLIOTECA E DOCUMENTAÇÃO - ESALQ/USP
}

\author{
Alves, Silvio André Meirelles \\ Epidemiologia da vassoura-d e-bruxa (C rinipellis pernic iosa (Stahel) \\ Singer) em caca ueiros enxerta dos em Uruçuça, BA / Silvio André Meirelles \\ Alves. - - Piracicaba, 2002. \\ $53 \mathrm{p}$. \\ Dissertação (mestrado) - - Escola Superior de Agricultura Luiz de \\ Queiroz, 2002. \\ Bibliografia. \\ 1. Cacau 2. Clonagem 3. Epidemiologia 4. Resistência genética 5. \\ Relação hospedeiro-patógeno 6. Vassoura-de-bruxa I. Título
}

CDD 633.74

"Permitida a cópia total ou parcial deste documento, desde que citada a fonte - $\mathrm{O}$ autor" 
Aos meus irmãos Cleide, Waldilene, Levi, Cibele, Ruth e Dulcinéia, que me apoiaram e incentivaram durante o curso.

\section{OFEREÇO}

Meu irmão João, cunhada Isabel e sobrinho Daniel (in memorian).

HOMENAGEIO

Aos meus pais, João e Dulce, as pessoas mais importantes em minha vida.

\section{DEDICO}




\section{AGRADECIMENTOS}

A Deus, por tudo que tem me proporcionado, pois todas as coisas foram feitas por ele, e sem ele nada do que foi feito se fez;

Ao prof. Dr. Armando Bergamin Filho pela orientação, amizade e confiança;

Ao Programa de Pós-Graduação em Fitopatologia da Escola Superior de Agricultura "Luiz de Queiroz" (ESALQ) da Universidade de São Paulo, pelas condições oferecidas;

À Almirante Cacau na pessoa de Martin Aitken, pelo apoio financeiro no início do curso e estadia em Itabuna;

Aos pesquisadores da Almirante Cacau: Dr. Alan Pomella, pela idealização e apoio para realização dos experimentos, pelas muitas conversas, sugestões, incentivo e amizade; Dra. Regina Machado pelos momentos de descontração e amizade;

Aos funcionários da Almirante Cacau, Edmilson, Jadenil, Marcos, Renilton, Toni, e outros que ajudaram desde a localização da área, limpeza e condução dos experimentos;

À professora Lilian Amorim pela ajuda nas várias etapas deste trabalho;

Ao professor Renato Ribeiro de Lima pela ajuda indispensável na análise estatística dos dados;

Ao Serviço de Promoção Social da Prefeitura do Campus "Luiz de Queiroz" pela concessão da Moradia Estudantil no primeiro ano do curso; 
Ao Conselho Nacional de Desenvolvimento Científico e Tecnológico (CNPq) pela concessão da bolsa de estudos no segundo ano do curso;

Aos professores e funcionários do Setor de Fitopatologia pela convivência, amizade e pelos ensinamentos aqui recebidos;

À Aliança Bíblica Universitária ( $\mathrm{ABU}$ ) pelos momentos de reflexão;

À Joana pelo apoio, compreensão, amor, paciência e incentivo durante esses dois anos de curso;

Aos colegas do curso de Pós-Graduação, em especial a Marissônia, Ana Paula, José Segundo, Luiz Fernando, Paulo, Ana Cláudia, Paulo de Tarso, Marilia, Solange, Leonardo, Marcel, Belasque, Cândido, Adriane, Liliane, Zaiame, Renata, Júlio, Alexandre, Rock, Valdir, Ivan, Daniel e a todos que direta ou indiretamente contribuíram para a realização deste trabalho. 


\section{SUMÁRIO}

Página

LISTA DE FIGURAS ................................................................................... viii

LISTA DE TABELAS ...............................................................................

CURRICULUM VITAE ....................................................................................... xii

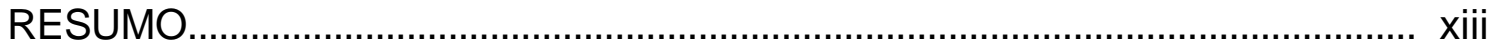

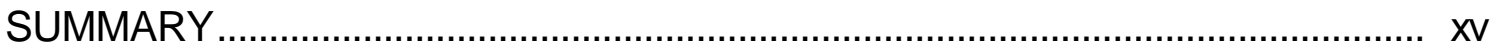

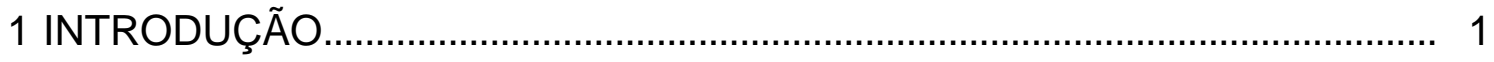

2 REVISÃO DE LITERATURA ......................................................................... 3

2.1 Ciclo da doença.................................................................................... 3

2.2 Gradiente de doença .............................................................................. 5

2.3 Curvas de progresso da doença ................................................................. 7

2.4 Controle cultural, químico e genético ............................................................ 8

3 MATERIAL E MÉTODOS …............................................................................. 10

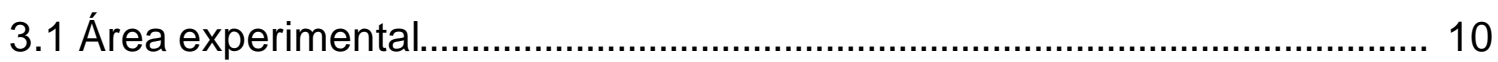

3.2 Material genético das plantas …................................................................ 10

3.3 Obtenção dos dados ................................................................................... 11

3.4 Gradiente de doença .................................................................................... 12

3.4.1 Fonte de inóculo .............................................................................. 12

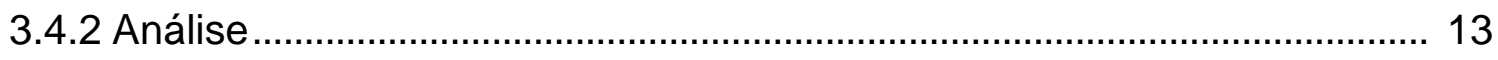

3.5 Curvas de progresso da doença ............................................................ 14

3.6 Comparação de métodos de controle e de genótipos .................................. 15

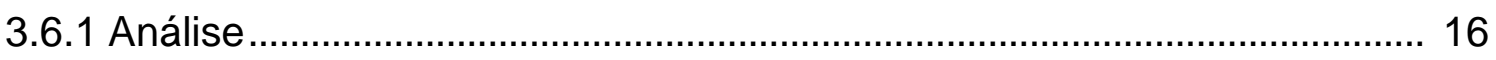

4 RESULTADOS E DISCUSSÃO ................................................................... 18 


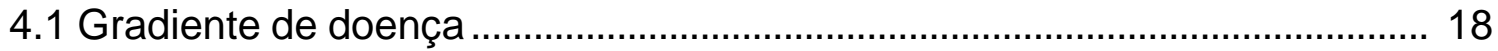

4.1.1 Fonte de inóculo ............................................................................... 18

4.1.2 Incidência na área experimental .......................................................... 19

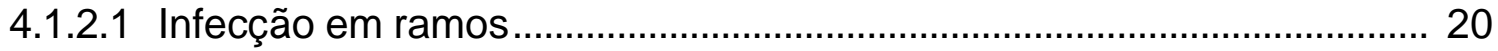

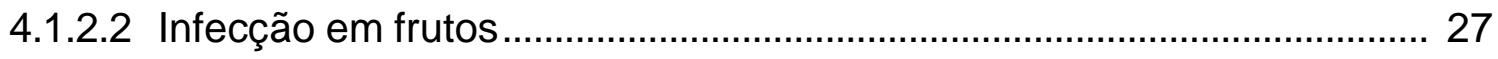

4.2 Curvas de progresso da doença ............................................................. 37

4.3 Comparação de métodos de controle e de genótipos .................................... 40

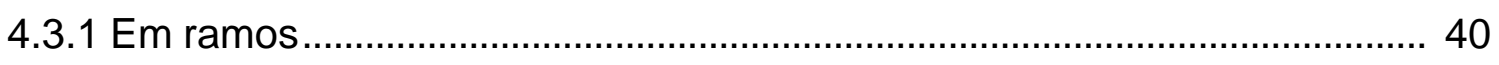

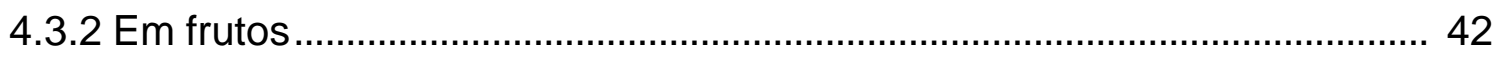

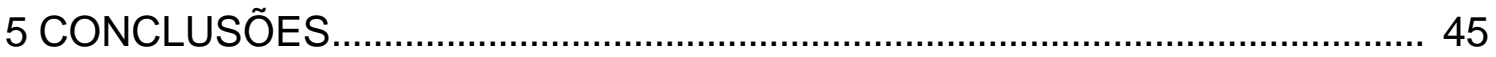

REFERÊNCIAS BIBLIOGRÁFICAS …............................................................ 46 


\section{LISTA DE FIGURAS}

Página

1 Croqui da área experimental e seus limites.

2 Gradientes de vassoura-de-bruxa do cacaueiro, quantificados em vassouras vegetativas, em todos os genótipos. Na safra principal, sub-área 1(A), sub-área 2 (B) e sub-área 3 (C). Na safra temporã, sub-área $1(D)$, sub-área $2(E)$ e sub-área $3(F)$

3 Gradientes de vassoura-de-bruxa do cacaueiro, quantificados em vassouras vegetativas, no genótipo NO-17. Na safra principal, subárea 1(A), sub-área 2 (B) e sub-área $3(\mathrm{C})$. Na safra temporã, subárea $1(D)$, sub-área $2(E)$ e sub-área $3(F)$.

4 Gradientes de vassoura-de-bruxa do cacaueiro, quantificados em vassouras vegetativas, no genótipo NO-24. Na safra principal, subárea $1(A)$, sub-área $2(B)$ e sub-área $3(C)$. Na safra temporã, subárea 1(D), sub-área $2(\mathrm{E})$ e sub-área $3(\mathrm{~F})$.

5 Gradientes de vassoura-de-bruxa do cacaueiro, quantificados em vassouras vegetativas, no genótipo NO-34. Na safra principal, subárea $1(A)$, sub-área $2(B)$ e sub-área $3(C)$. Na safra temporã, subárea 1(D), sub-área $2(E)$ e sub-área $3(F)$.

6 Gradientes de vassoura-de-bruxa do cacaueiro, quantificados em vassouras vegetativas, no genótipo NO-42. Na safra principal, subárea 1(A), sub-área 2 (B) e sub-área 3 (C). Na safra temporã, subárea $1(D)$, sub-área $2(E)$ e sub-área $3(F)$. 
7 Gradientes de vassoura-de-bruxa do cacaueiro, quantificados em frutos com vassoura, em todos os genótipos. Na safra principal, subárea $1(A)$, sub-área 2 (B) e sub-área $3(C)$. Na safra temporã, subárea $1(D)$, sub -área $2(E)$ e sub-área $3(F)$.

8 Gradientes de vassoura-de-bruxa do cacaueiro, quantificados em frutos com vassoura, no genótipo NO-17. Na safra principal, sub-área 1(A), sub-área 2 (B) e sub-área 3 (C). Na safra temporã, sub-área 1(D), sub-área $2(E)$ e sub-área $3(F)$.

9 Gradientes de vassoura-de-bruxa do cacaueiro, quantificados em frutos com vassoura, no genótipo NO-24. Na safra principal, sub-área 1(A), sub-área 2 (B) e sub-área 3 (C). Na safra temporã, sub-área 1(D), sub-área 2 (E) e sub-área $3(F)$.

10 Gradientes de vassoura-de-bruxa do cacaueiro, quantificados em frutos com vassoura, no genótipo NO-34. Na safra principal, sub-área 1(A), sub-área 2 (B) e sub-área 3 (C). Na safra temporã, sub-área 1(D), sub-área $2(E)$ e sub-área $3(F)$.

11 Gradientes de vassoura-de-bruxa do cacaueiro, quantificados em frutos com vassoura, no genótipo NO-42. Na safra principal, sub-área 1(A), sub-área 2 (B) e sub-área 3 (C). Na safra temporã, sub-área 1(D), sub-área $2(E)$ e sub-área $3(F)$.

12 Curvas de progresso da vassoura-de-bruxa do cacaueiro quantificada em vassouras vegetativas, nos tratamentos 1 (círculos vazios), 2 (quadrados) e 3 (triângulos). Ajuste epidemiológico (linha contínua). $(0=11 / 09 / 01)$.

13 Curvas de progresso da vassoura-de-bruxa do cacaueiro quantificada em frutos com vassoura, nos tratamentos 1 (círculos vazios), 2 (quadrados) e 3 (triângulos). Ajuste epidemiológico (linha contínua). $(0=11 / 09 / 01)$ 


\section{LISTA DE TABELAS}

Página

$1 \quad$ Número de repetições por genótipo e sub-área ....................................... 14

2 Número de repetições por genótipo e sub-área, com produção maior ou igual a um fruto na safra global........................................................... 17

3 Resultado das avaliações da área abandonada, constando a média de vassouras por planta e o desvio padrão

4 Média das contagens por planta de vassouras vegetativas (VV), frutos com vassoura (FV), frutos sadios (FS) e frutos com outros danos (OD) nas safras principal e temporã

5 Resultado das análises de regressão das contagens de vassoura vegetativa, na safra principal, aplicando a lei exponencial ....................... 20

6 Resultado das análises de regressão das contagens de vassoura vegetativa, na safra temporã, aplicando a lei exponencial ........................ 20

7 Resultado das análises de regressão das contagens de vassoura vegetativa, na safra principal, aplicando a lei exponencial, em quatro genótipos

8 Resultado das análises de regressão das contagens de vassoura vegetativa, na safra temporã, aplicando a lei exponencial, em quatro genótipos

9 Resultado das análises de regressão das contagens de frutos infectados com vassoura-de-bruxa, na safra principal, aplicando a lei exponencial 
10 Resultado das análises de regressão das contagens de frutos infectados com vassoura-de-bruxa, na safra temporã, aplicando a lei

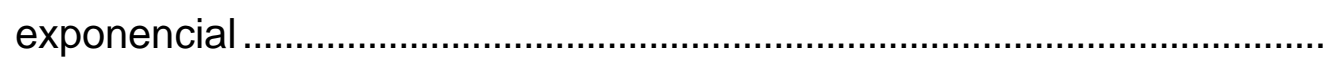

11 Resultado das análises de regressão das contagens de frutos infectados com vassoura-de-bruxa, na safra principal, aplicando a lei exponencial, em quatro genótipos

12 Resultado das análises de regressão das contagens de frutos infectados com vassoura-de-bruxa, na safra temporã, aplicando a lei exponencial, em quatro genótipos

13 Taxas médias de progresso da vassoura-de-bruxa do cacaueiro $(r)$ em diferentes tratamentos 39

14 Médias de vassouras vegetativas quantificadas na safra global

15 Análise de Deviance de frutos com vassoura computados na safra global

16 Porcentagem de frutos com vassoura (\%FV) em três tratamentos Tratamento 1 (poda semestral), Tratamento 2 (poda mensal), tratamento 3 (poda e aplicação de fungicida mensais)

17 Comparação das médias de percentual de frutos com vassoura (\%FV) em dez genótipos 


\section{CURRICULUM VITAE}

Silvio André Meirelles Alves, filho de João Furtado Alves e Dulce Meirelles Alves, nasceu em Juquiá - SP, em 23 de junho de 1977.

Em dezembro de 1994, concluiu o curso de técnico em agropecuária pela ETAE “Eng. Agr. Narciso de Medeiros” em Iguape - SP.

Em 2000, graduou-se em Agronomia pela Universidade Federal de Viçosa (UFV), em Viçosa - MG.

Em março de 2001, iniciou o curso de Mestrado em Fitopatologia, na Escola Superior de Agricultura "Luiz de Queiroz" (ESALQ) da Universidade de São Paulo, em Piracicaba - SP. 


\title{
EPIDEMIOLOGIA DA VASSOURA-DE-BRUXA (Crinipellis perniciosa (STAHEL) SINGER) EM CACAUEIROS ENXERTADOS EM URUÇUCA, BA
}

\author{
Autor: SILVIO ANDRÉ MEIRELLES ALVES \\ Orientador: Prof. Dr. ARMANDO BERGAMIN FILHO
}

\section{RESUMO}

A vassoura-de-bruxa é a doença mais importante da cultura do cacaueiro, nos países onde ela ocorre. Em 1989 foi constatada pela primeira vez a presença do patógeno causador dessa doença na principal região produtora do Brasil. A falta de medidas de controle eficientes resultou, nos últimos anos, em menor produção, mudanças no uso da terra, venda de propriedades, diminuição do nível de emprego e danos ao meio ambiente. Em vista do pouco conhecimento sobre aspectos epidemiológicos da doença nas condições do sudeste da Bahia, elaborou-se o presente trabalho com os seguintes objetivos: estudar o gradiente de infecção da vassoura-de-bruxa em ramos e frutos em cacaueiros enxertados; comparar o efeito de genótipos e três tratamentos (poda fitossanitária semestral, poda fitossanitária mensal e poda fitossanitária aliada a aplicação de fungicida mensais) no controle da doença; estudar o progresso da vassoura-de-bruxa no tempo, quantificado em ramos e frutos doentes. O experimento foi conduzido em Uruçuca, BA, em área contendo 16 genótipos diferentes, adjacente a uma área com cacaueiros abandonados com alta incidência da doença. A área experimental foi dividida em três partes, as quais receberam os seguintes tratamentos: poda fitossanitária semestral, poda fitossanitária mensal e poda fitossanitária aliada a 
aplicação de fungicida mensal. Pelo menos uma vez por mês foram contados os ramos e frutos com vassoura. Os resultados mostraram a ausência de evidência clara da existência de gradiente de doença. Os níveis de resistência genética à vassoura-de-bruxa de ramos e frutos não foram correlacionados entre si. Houve bom ajuste do progresso da doença ao modelo monomolecular. As menores taxas de crescimento foram obtidas no tratamento com poda e aplicação de fungicida mensal. O tratamento que combinou poda e pulverização com fungicida apresentou diferença significativa na redução do percentual de frutos com vassoura. Os genótipos NO-34, NO-17 e NO-02 foram os que apresentaram menores percentagens de frutos com vassoura, sendo significativamente diferentes dos genótipos NO-24 e NO-13. 


\title{
EPIDEMIOLOGY OF WITCHES' BROOM (Crinipellis perniciosa (STAHEL) SINGER) ON GRAFTED COCOA IN URUCUCA, BA
}

\author{
Author: SILVIO ANDRÉ MEIRELLES ALVES \\ Adviser: Prof. Dr. ARMANDO BERGAMIN FILHO
}

\section{SUMMARY}

Witches' broom is the most important disease of cocoa, in the countries where it occurs. In 1989, it was verified for the first time the presence of the pathogen in the main producing area of Brazil. The lack of efficient control measures resulted, in the last years, in losses in the production, changes in the use of the soil, sale of properties, decrease of the employment level and damages to the environment. In view of the little knowledge on epidemic aspects of the disease in the conditions of the southeast of Bahia, the present work was elaborated with the following objectives: to study the gradient of the witches' broom infection in flushes and pods in grafted cocoa; to compare the effect of genotypes and three treatments (half-yearly phytosanitation, monthly phytosanitation and monthly phytosanitation allied to fungicide application) in the control of the disease; to study the witches' broom temporal progress, quantified in flushes and pods. Trials were carried out in Uruçuca, BA, in area contends 16 different genotypes, adjacent an area with abandoned cocoa with high incidence of the disease. The experimental area was divided in three parts, which received the following treatments: half-yearly phytosanitation, monthly phytosanitation and monthly phytosanitation allied to fungicide application. At least once a month, flushes and 
pods with broom were counted. Results showed the absence of clear evidence of the existence of disease gradient. The levels of genetic resistance to the witches' broom of flushes and pods were not correlated to each other. There was good adjustment of progress of the disease to the monomolecular model. The smallest growth rates were obtained in the treatment with monthly phytosanitation and fungicide application. The treatment that allied phytosanitation and fungicide application presented significant difference in the reduction of the percentage of witches' broom infected pods. The genotypes NO-34, NO-17 and NO-02 presented smaller percentages of diseased pods, being significantly different from the genotypes NO-24 and NO-13. 


\section{INTRODUÇÃO}

O cacaueiro (Theobroma cacao L.) é uma planta pertencente à família Sterculiaceae, provavelmente originada da Bacia Amazônica e cultivada nas regiões tropicais do mundo. $O$ interesse de cultivo desta espécie está no aproveitamento de suas sementes (amêndoas) para produção de manteiga de cacau e chocolate.

Assim como o café e a cana-de-açúcar, a cultura do cacau marcou época na economia brasileira, sendo uma das principais fontes geradoras de divisas na década de 70 . Nessa época, cerca de $90 \%$ da produção era destinada àexportação (Bastos, 1987).

Nesse período, as principais regiões produtoras se localizavam na Amazônia e no Estado da Bahia, sendo este último responsável por cerca de $80 \%$ da produção nacional. Na safra 1984/1985 o Brasil foi o segundo maior produtor mundial de amêndoas, produzindo aproximadamente 400.000 toneladas, mas de acordo com os dados de 2000, a produção caiu para 210.000 toneladas (FAO, 2002). Assim, a partir de 1997, o Brasil passou a importar o produto. Em 2000 foram importadas cerca de 71.000 toneladas de amêndoas de cacau (Companhia das Docas do Estado da Bahia, 2002).

A queda da produção nacional nos últimos anos pode ser explicada, em parte, pela introdução do patógeno causador da vassoura-debruxa do cacaueiro (Crinipellis perniciosa (Stahel) Singer) na Bahia, em 1989 (Pereira et al., 1990).

O maior impedimento à produção de cacau no Brasil é causado pelas doenças fúngicas e, dentre elas, a vassoura-de-bruxa é a mais importante 
(Almeida \& Andebrhan, 1987 e Luz et al., 1997). Os danos à produção no estado da Bahia, devido à vassoura-de-bruxa, foram de aproximadamente 105 mil toneladas nas safras 1995/1996 e 1996/1997 (Santos Filho et al., 1998).

Além de impactos econômicos resultantes da menor produção de cacau, outras mudanças ocorreram na região produtora da Bahia, como: uso da terra, venda de propriedades, nível de emprego e danos ao meio ambiente (Trevizan, 1996).

Atualmente, uma das recomendações da CEPLAC, para a reabilitação de plantas suscetíveis à vassoura-de-bruxa, é o uso de variedades clonais resistentes, por meio da enxertia (Rosa, 1998).

Considerando a necessidade de conhecimentos epidemiológicos nas condições do sudeste baiano, os objetivos deste trabalho foram:

- Estudar o gradiente de infecção da vassoura-de-bruxa em ramos e frutos de cacaueiros clonados;

- Comparar o efeito de genótipos e três tratamentos (poda fitossanitária semestral, poda fitossanitária mensal e poda fitossanitária aliada a aplicação de fungicida mensais) no controle da doença;

- Estudar o progresso da vassoura-de-bruxa no tempo, quantificado em ramos e frutos doentes.

Os estudos de gradiente e progresso da doença no tempo, em diversos materiais genéticos nas condições climáticas do sudeste da Bahia, resultarão em melhor entendimento da interação patógeno-hospedeiro, bem como na adequada manutenção da resistência genética e implementação de estratégias de controle integrado. 


\section{REVISÃO DE LITERATURA}

\subsection{Ciclo da doença}

A doença vassoura-de-bruxa é causada pelo fungo Crinipellis perniciosa (Stahel) Singer, e sua provável origem é a bacia amazônica, onde ocorre de forma endêmica (Baker \& Crowdy, 1943 e Holliday, 1952).

Os basidiósporos se constituem nas únicas estruturas, encontradas em condições de campo, capazes de infectar o cacaueiro (Purdy \& Schmidt, 1996). Esses são produzidos em lamelas localizadas na parte inferior do píleo do basidiocarpo. Os basidiósporos são unicelulares, hialinos, com parede fina, medindo cerca de $12 \mu \mathrm{m} \times 6 \mu \mathrm{m}$ (Baker \& Crowdy, 1943).

A condição ambiental primordial para a liberação dos basidiósporos é a umidade relativa do ar próxima à saturação e temperaturas entre 20 e $30 \stackrel{\circ}{\circ}$ (Rocha \& Wheeler, 1985). Os basidiósporos são muito sensíveis àluz ultravioleta e são facilmente dessecados, perdendo rapidamente sua capacidade de germinação. Entretanto, a liberação noturna garante a sua sobrevivência por mais tempo. Sob condições de campo, em Trinidad e no Equador, a maior liberação œorreu entre $22 \mathrm{~h}$ e $4 \mathrm{~h}$, com umidade relativa maior que $95 \%$ e temperaturas entre 20 e $24 \stackrel{\circ}{\circ}$ (Baker \& Crowdy, 1943 e Evans \& Solorzano, 1982).

A dispersão dos basidiósporos se dá principalmente pelo vento. A altura em que o basidiocarpo é produzido é muito importante no progresso da doença (Costa, 1993). Vassouras na superfície do solo produzem poucos basidiocarpos e com menor chance do basidiósporo atingir os órgãos 
suscetíveis; fontes mais altas permitem a disseminação a maiores distâncias (Andebrhan et al., 1993). As vassouras localizadas na copa são as principais fontes de inóculo (Andebrhan, 1985b e Costa, 1993). Por outro lado, há estudos nas condições da Bahia, mostrando que os casqueiros também são importantes fontes de inóculo (Niella, 1997).

A chuva também possui importância na disseminação da doença dentro de uma mesma planta e entre plantas vizinhas (Andebrhan, 1987).

A infecção ocorre quando basidiósporos são depositados sobre gemas vegetativas ou florais em expansão, ou em frutos jovens. Nas gemas dormentes a infecção torna-se latente, assumindo o aspecto de pequenos pontos necróticos que entram em atividade quando a planta reinicia a brotação (Bastos, 1994).

A penetração do basidiósporo se dá por meio de estômatos, ferimentos (Frias et al., 1991 e Sreenivasan \& Dabydeen, 1989) ou diretamente (Sreenivasan \& Dabydeen, 1989). Nesse estádio da doença o patógeno se comporta como biotrófico, crescendo intercelularmente, com hifas entumecidas, sem grampos de conexão e talo monocariótico (Evans \& Bastos, 1979). O desenvolvimento do patógeno causa uma desordem fisiológica no hospedeiro, provavelmente interferindo no balanço hormonal, resultando em hipertrofia e hiperplasia de células. Nos ramos, a hipertrofia é acompanhada de brotação intensa de gemas laterais, dando a característica de uma vassoura. Os brotos infectados são de diâmetro cerca de três vezes maior que os sadios, com entrenós curtos e folhas geralmente grandes, curvadas e retorcidas (Baker \& Crowdy, 1943).

Para a determinação do período de suscetibilidade dos frutos, a idade é um parâmetro melhor que o seu tamanho. Os frutos até 12 semanas após a polinização são suscetíveis à infecção, entre 12 e 15 semanas podem apresentar pontos necróticos nas amêndoas, e acima de 15 semanas não são infectados (Andebrhan, 1981 e 1985b). 
O período de incubação (intervalo de tempo entre a infecção e o aparecimento dos sintomas) varia de quatro a seis semanas (Baker \& Crowdy, 1943). Decorrido esse tempo, as vassouras secam e morrem, tornando-se necróticas. Nesse novo estádio, que varia de 17 a 25 semanas (Baker \& Crowdy, 1943 e Holliday, 1952), o patógeno torna-se saprofítico, crescendo intracelularmente com hifas mais delgadas (Evans \& Bastos, 1979 e Silva \& Matsuoka, 1999).

Em locais com estação seca definida, o patógeno sobrevive dormente nas vassouras secas e frutos mumificados até o início da estação chuvosa, quando basidiocarpos são formados (Baker \& Crowdy, 1943). Em locais com chuvas bem distribuídas, como no sudeste do Estado da Bahia, basidiocarpos podem ser formados ao longo do ano (Luz et al., 1997).

Não há separação temporal entre tecido hospedeiro e inóculo do patógeno, sendo que não há prolongado período de dormência para ambos. Há períodos de maior e menor ocorrência da doença, especialmente em áreas com prolongados períodos secos, com o fim de um ciclo de doença durante a estação seca e o início de outro ciclo da doença com o advento da estação chuvosa (Maddison et al., 1993b).

O patossistema é predominantemente monocíclico (Tovar, 1991), mas cerca de $20 \%$ de vassouras vegetativas podem produzir basidiocarpos dentro de um mesmo ano (Andebrhan, 1985a e Baker et al., 1941).

\subsection{Gradiente de doença}

O gradiente de doença é uma das formas de se estudar 0 crescimento espacial de uma epidemia (Amorim, 1995 e Bergamin Filho et al., 2002). Baseia-se na análise da diminuição dos níveis de infecção com o aumento da distância de uma fonte de inóculo. A importância do estudo de gradiente está no melhor conhecimento da capacidade de dispersão do patógeno, do potencial de distribuição das estruturas infectivas no campo, 
resultando, assim, em informações importantes para o controle integrado da doença.

As primeiras observações em condições de campo, realizadas em Trinidad, indicaram que áreas sob remoção contínua adjacente à área sem controle da doença apresentavam um número decrescente de vassouras com o aumento da distância da área sem controle (Baker et al., 1941).

Em experimento realizado no Equador, usando como fonte de inóculo vassouras suspensas numa área isolada cerca de $800 \mathrm{~m}$ de outras plantações de cacau, usaram-se mudas de cacau com cinco meses de idade. Porém, antes que basidiocarpos fossem produzidos no vassoureiro, mudas se tornaram doentes indicando que basidiósporos poderiam se disseminar por mais de $800 \mathrm{~m}$ (Evans \& Solorzano, 1982).

A necessidade de informações sobre a dispersão do patógeno continuou e nove anos mais tarde, experimento semelhante foi realizado no mesmo país. Usou-se um primeiro grupo de mudas com dois meses de idade e 21 dias de exposição ao campo; um segundo grupo com mudas de cinco meses de idade e 90 dias de exposição; e estimou-se o número de basidiósporos por $\mathrm{m}^{3}$ de ar com armadilha tipo rotorod. Nos dois grupos a distância máxima passível de verificação foi de $285 \mathrm{~m}$ da fonte. Como resultado determinou-se que os basidiósporos foram capazes de infectar mudas até essa distância, porém a distância máxima não pôde ser determinada. A regressão obtida com os dados do grupo de mudas expostas por 21 dias mostrou uma inclinação mais pronunciada. A curva da concentração de basidiósporos nas diferentes distâncias apresentou-se semelhante à curva de infecção das mudas (Aragundi et al., 1987).

No Brasil realizou-se um experimento em Rio Negro, AM, num corredor limpo de $8 \mathrm{~m}$ por $400 \mathrm{~m}$, em floresta primária, com o objetivo de verificar o efeito de diferentes alturas da fonte de inóculo na dispersão horizontal do patógeno (até $320 \mathrm{~m}$ ). Mudas com aproximadamente três meses de idade foram expostas na superfície do solo, a 1, 2 e $3 \mathrm{~m}$ de altura. Como 
resultado, obteve-se que fontes posicionadas a 1, 2, e $3 \mathrm{~m}$ ou todas as alturas ao mesmo tempo, proporcionaram um gradiente decrescente com o aumento da distância. A fonte de inóculo localizada na superfície do solo resultou em dois terços menos incidência de doença que ras outras alturas (Andebrhan et al., 1993).

\subsection{Curvas de progresso da doença}

A análise temporal de uma epidemia pode ser obtida construindose curvas de crescimento da doença, conhecida como curvas de progresso da doença (Bergamin Filho, 1995).

No patossistema cacaueiro-Crinipellis perniciosa o progresso da doença é muito dependente das condições ambientais, pois estas afetam a produção de basidiósporos do patógeno e a fenologia do hospedeiro (Andebrhan, 1982 e Rudgard, 1987a)

Muitos trabalhos de quantificação da doença tiveram como objetivo determinar, ao longo dos meses do ano, os períodos de pico de produção dos sintomas e/ou produção de basidiocarpos (Andebrhan, 1985a; Baker et al., 1941; Cifuentes et al., 1982; Costa, 1993 e Rudgard, 1987b). Por outro lado, poucos trabalhos apresentaram curvas cumulativas de doença, para assim determinar as taxas de progresso. Embora Rudgard (1987a) não tenha ajustado equações aos dados de frutos e ramos infectados, pelo gráfico apresentado em seu trabalho, as curvas são características do crescimento monomolecular.

Experimentos realizados nas condições da Amazônia brasileira mostraram taxas de infecção em ramos entre 0,1 e 1,2 vassouras/planta/dia (Andebrhan, 1982). 


\subsection{Controle cultural, químico e genético}

As infecções causadas por Crinipellis perniciosa em cacaueiro não são sistêmicas, o que permite o controle da enfermidade pela remoção de partes doentes da planta (Baker \& Crowdy, 1943).

A remoção duas vezes ao ano é bastante adequada para regiões com estação seca definida, resultando em baixos níveis de infecção ao final de um ano. Na Amazônia, quando a eliminação de partes infectadas é realizada nas épocas recomendadas, podem-se baixar os danos àníveis tão baixos como $3 \%$ no ano seguinte àpratica (Almeida \& Andebrhan, 1987).

Regiões com alta precipitação ou com chuvas bem distribuídas ao longo do ano proporcionam condições favoráveis à ocorrência da doença, indicando maior número de remoções por ano (Luz et al., 1997), até intervalos semanais (Soberanis et al., 1999). A depender do intervalo de remoção de vassouras e das condições locais, níveis de até $80 \%$ de infecções no fruto ainda podem ocorrer (Tollenaar, 1959).

O custo da remoção é função do nível de infecção e altura das plantas, pois quanto maior o número de ramos doentes e altura da planta, mais difícil e demorada é a execução da prática (Almeida \& Andebrhan, 1987). Em geral, a remoção é econômica em áreas com produtividades acima de 600 kg/ha/ano (Almeida et al., 1988; Almeida \& Andebrhan, 1987; Rudgard \& Andebrhan, 1987 e Soberanis et al., 1999), a depender do preço do cacau (Rudgard \& Andebrhan, 1987).

Dentre os produtos utilizados no controle químico da doença, o óxido cuproso é o que apresenta resultados mais positivos em condições de campo, além de ser recomendado para o controle da podridão parda. $\mathrm{O}$ óxido cuproso não proporciona boa proteção contra a formação de vassouras vegetativas (Almeida, et al., 1998 e Luz et al., 1997). A dosagem recomendada

é de $3 \mathrm{~g}$ de cobre metálico por planta mensalmente ou $6 \mathrm{~g}$ por planta bimestralmente. O principal objetivo da aplicação desse fungicida é a proteção 
de frutos jovens, porém sua eficiência não é total, pois há rápida expansão da superfície do fruto nos primeiros três meses, não permitindo boa cobertura dos mesmos (Soberanis et al., 1999). A precipitação também pode remover significativamente os depósitos de cobre nos frutos (Costa \& Matuo, 1999).

Uma forma interessante de controle que tem apresentado bons resultados é a combinação de remoção de partes doentes e aplicação de fungicidas protetores (Almeida, et al., 1998).

O uso de variedades resistentes, é sem dúvida, a forma mais econômica para o controle da doença. A primeira introdução de cacau na região baiana ocorreu em 1888. Até a década de 70 do século passado, haviam sido realizados apenas quatro períodos de introdução, com baixa variabilidade genética. No período de 1970 a 1979 ocorreu a implantação de núcleos de cacaueiros e distribuição de sementes híbridas (Silva \& Cardoso, 1980).

Trabalhos de seleção realizados em Trinidad mostraram que os genótipos SCA-6 e SCA-12 eram livres da vassoura-de-bruxa. Posteriormente, porém, nas condições de campo, mostraram-se suscetíveis. Mesmo assim os referidos genótipos continuam sendo usados em cruzamentos para a incorporação de genes, obtendo-se bons resultados práticos (Andebrhan et al., 1998).

Estudos realizados em Ouro-Preto d'Oeste, PA, mostraram comportamento diferencial de híbridos na produção de vassouras ativas e número de basidiocarpos por vassoura. Do ponto de vista epidemiológico, a maioria das combinações com PA-150 produziu grande quantidade de basidiocarpos. Melhores resultados foram obtidos em combinações com IMC67. Embora os híbridos SCA-6 não tenham apresentado bons resultados, houve baixo número de vassouras por planta (Andebrhan \& Almeida, 1985a). 


\section{MATERIAL E MÉTODOS}

\section{1 Área experimental}

O experimento foi conduzido na Fazenda Novo Oriente, pertencente ao município de Uruçura, BA. A área apresenta topografia plana a ligeiramente ondulada, onde foram demarcadas três sub-áreas experimentais retangulares de $15 \mathrm{~m}$ por $460 \mathrm{~m}$ e duas faixas de $10 \mathrm{~m}$ por $460 \mathrm{~m}$ que foram usadas como bordadura para separar as sub-áreas.

A área experimental escolhida foi formada por uma mistura de plantas, com 16 genótipos diferentes, distribuídos aleatoriamente, enxertados sobre cacaueiro adulto. O sombreamento é de cerca de $50 \%$ e toda a área foi submetida a contínuo controle de plantas daninhas, por meio de roçagens. Essa área possui em seus limites: área de cacaueiro abandonado, mata secundária, um riacho seguido de pastagem e área de cacaueiro enxertado com genótipos resistentes (Figura 1).

Dentro da área experimental foram realizados estudos de gradiente da doença, progresso da doença no tempo e comparação de métodos de controle e resistência dos genótipos.

\subsection{Material genético das plantas}

Os genótipos utilizados nos experimentos são resultantes de seleção na própria fazenda a partir do ano de 1996. O proprietário foi orientado por Engenheiros Agrônomos da Comissão Executiva do Plano da Lavoura 
Cacaueira (CEPLAC) para que as plantas menos infectadas fossem identificadas e utilizadas como matrizes. Assim, cerca de 100 matrizes foram selecionadas e acompanhadas. Das melhores foram retirados ramos para proceder a renovação de toda a fazenda.

\begin{tabular}{|c|c|c|c|}
\hline \multirow{7}{*}{ 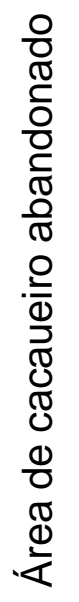 } & Floresta com mata secundária & \multirow{7}{*}{$\begin{array}{l}\frac{O}{\bar{O}} \\
\frac{\tilde{T}}{\tilde{x}}\end{array}$} & \multirow{7}{*}{ 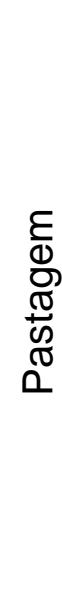 } \\
\hline & Sub-área 1 (15 m x 460 m) & & \\
\hline & Bordadura (10 m x $460 \mathrm{~m})$ & & \\
\hline & Sub-área 2 (15 m x 460 m) & & \\
\hline & Bordadura (10 m x $460 \mathrm{~m})$ & & \\
\hline & Sub-área 3 (15 m x 460 m) & & \\
\hline & Área de cacaueiro enxertado com genótipos resistentes & & \\
\hline
\end{tabular}

Figura 1 - Croqui da área experimental e seus limites.

As plantas da área experimental possuem identificação em placa metálica, contendo a data da enxertia (mês e ano) e o material enxertado (sigla composta das letras "NO", seguido de dois números).

\subsection{Obtenção dos dados}

A área experimental foi demarcada no mês de abril de 2001. em seguida, todas as flores e frutos foram removidos da mesma, para que o experimento não sofresse interferência de práticas anteriores. Os dados utilizados para os cálculos foram aqueles coletados na ocasião da colheita, entre os meses de setembro de 2001 e julho de 2002. O intervalo de colheita variou de 2 a 5 semanas.

Os dados obtidos entre os meses de setembro de 2001 e fevereiro de 2002 foram considerados como pertencentes a safra principal e aqueles resultantes das colheitas dos meses de março a agosto de 2002, foram 
considerados como os da safra temporã (Carzola et al., 1989). A soma das colheitas da safra principal e temporã foi denominada como safra global.

$\mathrm{Na}$ realização de cada uma das colheitas foram quantificados os ramos doentes e os frutos maduros. Os frutos foram classificados como: sadios, com vassoura ou outros danos. Consideraram-se como frutos sadios aqueles sem sintomas de doenças externamente; frutos com vassoura, os que apresentaram sintomas típicos de vassoura-de-bruxa, que na maioria das vezes eram lesões necróticas externas acompanhadas de necrose nas amêndoas; os frutos classificados como outros danos, foram aqueles que receberam ataque de insetos, roedores ou outras doenças.

Não foram quantificados os frutos produzidos nos porta-enxertos e os frutos tipo peco, ou seja, frutos que não vingaram em virtude de distúrbios de natureza fisiológica. Todos frutos colhidos foram quebrados no próprio campo, e em seguida, todas as cascas foram retiradas da área.

Os dados foram coletados das plantas que possuíam a identificação do material enxertado e data de enxertia nos anos de 1998 e 1999. Para facilitar a localização das plantas e a anotação dos dados, optou-se em reidentificá-las com números seqüenciais.

Para fins de estudo de gradiente, normalmente utiliza-se para localização das plantas as próprias linhas de plantio, porém nessa área o espaçamento das plantas era irregular; assim, a localização foi realizada pela divisão da área em seções transversais de $10 \mathrm{~m}$ a partir da fonte de inóculo, como já foi utilizado em outro trabalho (Maddison et al., 1993a).

\subsection{Gradiente de doença}

\subsubsection{Fonte de inóculo}

Foi utilizada como fonte de inóculo uma área adjacente à experimental, pertencente à Fazenda Brasil, com cacaueiros da variedade 
comum, safreiros, abandonados e com alta incidência da doença (Figura 1). Nos meses de abril de 2001 e junho de 2002 realizaram-se contagens do número de vassouras vegetativas para quantificar o potencial de inóculo nessa área. Essas quantificações foram realizadas contando-se todas as vassouras verdes e secas de quinze plantas escolhidas aleatoriamente. A contagem de frutos doentes foi desconsiderada devido ao alto índice de frutos secos e atacados por roedores, dificultando a determinação precisa da incidência da vassoura-de-bruxa nesses frutos.

\subsubsection{Análise}

As curvas de gradiente foram obtidas usando-se os dados de todos os genótipos em conjunto e, separadamente, dos quatro mais abundantes. Na análise conjunta dos genótipos foram utilizadas as seguintes repetições: 278 plantas na sub-área 1, 279 plantas na sub-área 2 e 281 plantas na sub-área 3. Os quatro genótipos mais abundantes foram: NO-17, NO-24, NO-34 e NO-42, as repetições desses genótipos podem ser observadas na Tabela 1. Foram ajustadas curvas para cada safra utilizando-se de dois modelos empíricos, conhecidos como lei da potência e lei exponencial (Bergamin Filho et al., 2002). A lei da potência é dada por $y=a d^{-b}$, onde $y=$ intensidade de doença, $d$ = distância da fonte, $a$ = parâmetro relacionado com a força da fonte e $b=$ inclinação do gradiente; na lei exponencial $y=a^{-b d}$. Na forma linearizada, esses modelos são escritos como: $\ln y=\ln a-b \ln d$, e $\ln y=$ In $a-b d$, respectivamente.

A doença foi quantificada pelo somatório de ramos e frutos doentes no período de cada safra. Foram calculadas médias das incidências para cada $10 \mathrm{~m}$ a partir da fonte de inóculo. Aos valores de vassouras vegetativas e frutos com vassoura não foi aplicada a transformação de múltiplas infecções (Gregory, 1973). Após o cálculo da análise de variância, o coeficiente angular e o coeficiente de determinação foram comparados. 
Tabela 1. Número de repetições por genótipo e sub-área

\begin{tabular}{cccc}
\hline \multirow{2}{*}{ Genótipos } & \multicolumn{3}{c}{ Sub-áreas } \\
\cline { 2 - 4 } NO-02 & 1 & 2 & 3 \\
NO-10 & 9 & 7 & 3 \\
NO-12 & 40 & 12 & 17 \\
NO-13 & 6 & 10 & 6 \\
NO-17 & 20 & 22 & 8 \\
NO-24 & 32 & 33 & 21 \\
NO-34 & 64 & 44 & 14 \\
NO-42 & 43 & 61 & 33 \\
NO-50 & 12 & 13 & 28 \\
NO-52 & 10 & 12 & 10 \\
NO-56 & 6 & - & 14 \\
NO-63 & - & 29 & - \\
NO-22 & - & - & - \\
NO-36 & - & - & 18 \\
NO-38 & - & - & 21 \\
NO-53 & - & 279 & 83 \\
Total & 278 & & 281 \\
\hline
\end{tabular}

\subsection{Curvas de progresso da doença}

Dos 16 genótipos presentes na área experimental, dez se repetiam nas três sub-áreas (Tabela 1). Esses foram os utilizados nas análises de crescimento da doença em função do tempo. A plotagem da proporção de doença em função do tempo mostrou típico crescimento monomolecular.

O cálculo da proporção de doença foi baseado nos valores médios de doença por planta. A proporção de doença de cada data foi obtida realizando-se a divisão entre a média daquela data e a maior média acumulada.

Foram realizados ajustes para a contagem de vassouras vegetativas, no período de setembro de 2001 a julho de 2002, para as três subáreas. A mesma metodologia foi utilizada para a contagem de frutos com vassoura, no período de setembro de 2001 a janeiro de 2002, ou seja, na safra principal. O grau de ajuste do modelo foi determinado em função dos valores do coeficiente de determinação $\left(R^{2}\right)$. As sub-áreas foram comparadas por meio 
dos valores das taxas de progresso $(r)$. Para o cálculo de $r$, os dados de proporção de doença foram transformados utilizando-se Monito $(Y)=\left(\ln (1 /)_{1}-\right.$ Y))); em seguida, as taxas foram obtidas por meio da regressão linear dos dados transformados em função do tempo.

\subsection{Comparação de métodos de controle e de genótipos}

Em cada sub-área aplicou-se um tratamento. Na sub-área 1 houve remoção semestral das vassouras vegetativas, na sub-área 2 a freqüência de remoção foi mensal, e na sub-área 3 , mensalmente, foi realizada remoção e aplicação de fungicida. A opção de se fazer a remoção mensal em toda a área (com exceção da sub-área 1) foi devido às plantas serem ainda jovens (dois e três anos, no início do experimento) e ao baixo número de ramos doentes por planta.

Os ramos doentes foram quantificados pelo menos uma vez por mês. Na sub-área 1 eles foram marcados com uma fita para que não houvesse recontagem da vassoura. As remoções foram realizadas em dezembro de 2001 e em junho de 2002. Nas sub-áreas 2 e 3 logo após a contagem os mesmos foram removidos.

As vassouras removidas foram picadas e colocadas em contato com o solo junto æ̀ folhas do chão, para que as mesmas encontrassem condições para sua rápida degradação (Luz et al., 1997) e, assim, impedir a reprodução do patógeno.

$\mathrm{Na}$ sub-área 3, o óxido cuproso foi o fungicida utilizado por apresentar bons resultados em condições de campo, ser amplamente testado (Almeida et al., 1998 e Costa \& Matuo, 1999), além de ser recomendado para o controle da doença podridão parda, causada por Phytophthora spp. O objetivo do uso do fungicida foi a proteção dos frutos, porém a aplicação foi realizada em toda a planta, imaginando-se quatro faces em cada planta, fazendo-se movimentos para cima e para baixo. Foi utilizado o fungicida Cobre Sandoz BR, 
que contém $50 \%$ de cobre ativo, na dosagem de $3 \mathrm{~g}$ de i.a./cacaueiro/aplicação (Almeida et al., 1998), mensalmente, entre maio de 2002 e abril de 2003.

\subsubsection{Análise}

O delineamento experimental foi o inteiramente casualizado com três tratamentos, dez genótipos e diferentes números de repetições. Cada planta foi considerada como uma parcela experimental. No cálculo das médias de contagem de vassouras vegetativas, foram utilizadas as mesmas repetições do item 3.5. $\mathrm{Na}$ análise da porcentagem de frutos com vassoura, foi necessário retirar as plantas que não produziram frutos na safra global, portanto, foram usadas as plantas pertencentes aos dez genótipos, que se repetiam nas três sub-áreas e produziram pelo menos um fruto na safra global (Tabela 2).

A percentagem de frutos com vassoura (\%FV) foi determinada para cada planta, no final do período de avaliação, multiplicando-se por 100 a proporção entre frutos com vassoura $(F V)$ e total de frutos colhidos naquela planta.

Dados de proporções são analisados, geralmente, utilizando-se um modelo de regressão considerando que a variável resposta tenha distribuição binomial. Os modelos lineares generalizados englobam esta teoria de modelagem estatística e foi introduzido por Nelder \& Wedderburn (1972) como uma extensão da teoria de modelos lineares clássicos. Uma discussão sobre o assunto pode ser encontrada em McCullagh \& Nelder (1989).

Considerando os dados deste trabalho, pode-se denominar que $Y_{i}$ corresponde ao percentual de frutos com vassoura (\%FV), de um total de $m_{i}$ frutos, sendo $i=1,2, \ldots, n$ e $n$ o número total de plantas. Sendo os $Y_{i}$ 's variáveis aleatórias, o modelo binomial assume que $Y_{i} \sim \operatorname{Bin}\left(m_{i}, \pi_{i}\right)$, em que $\pi_{i}$ é a probabilidade de $\% \mathrm{FV}$, com média $\mu_{i}=E\left(Y_{i}\right)=m_{i} \pi_{i}$ e variância $\operatorname{Var}\left(Y_{i}\right)=m_{i} \pi_{i}(1-$ $\pi_{i}$ ). O modelo linear generalizado permite modelar as proporções esperadas $\pi_{i}$ em termos de variáveis explanatórias $x_{i}$ (efeitos de tratamento e genótipos) 
através de $g\left(\pi_{i}\right)=x_{i}^{\prime} \beta$, em que $g$ é uma função de ligação adequada e $\beta$ é o vetor de parâmetros. O logito é a função de ligação mais comum para o modelo binomial, e foi a utilizada no presente trabalho, ou seja, $g\left(\pi_{i}\right)=\ln \left(\pi_{i} /\left(1-\pi_{i}\right)\right)$.

Tabela 2. Número de repetições por genótipo e sub-área, com produção maior ou igual a um fruto na safra global

\begin{tabular}{cccc}
\hline \multirow{2}{*}{ Genótipos } & \multicolumn{3}{c}{ Sub-áreas } \\
\cline { 2 - 4 } NO-02 & 1 & 2 & 3 \\
NO-10 & 30 & 7 & 2 \\
NO-12 & 9 & 33 & 12 \\
NO-13 & 33 & 10 & 6 \\
NO-17 & 5 & 10 & 8 \\
NO-24 & 19 & 16 & 15 \\
NO-34 & 26 & 27 & 14 \\
NO-42 & 46 & 33 & 21 \\
NO-50 & 29 & 41 & 14 \\
NO-52 & 4 & 8 & 5 \\
Total & 9 & 12 & 13 \\
\hline
\end{tabular}

Para verificar se o modelo proposto ficou bem ajustado aos dados, utilizou-se a análise de deviance, a qual é uma generalização da análise de variância, proposta por McCullagh \& Nelder (1989). As análises foram feitas com o software SAS (Statistical Analysis System), versão 8.00 (SAS, 1999). 


\section{RESULTADOS E DISCUSSÃO}

\subsection{Gradiente de doença}

\subsubsection{Fonte de inóculo}

A contagem preliminar à instalação do experimento, em abril de 2001, para quantificar o potencial de inóculo da área abandonada, revelou uma incidência de 82,0 vassouras vegetativas por planta. Em junho de 2002 a incidência média por planta foi de 104,0 vassouras (Tabela 3).

Tabela 3. Resultado das avaliações da área abandonada, constando a média de vassouras por planta e o desvio padrão

\begin{tabular}{lrrrr}
\hline \multirow{2}{*}{ Data } & \multicolumn{3}{c}{ Média de vassouras $^{*}$ Desvio padrão $^{1}$} \\
\cline { 2 - 4 } & Secas & Verdes & Total & \\
\hline $04 / 2001$ & 62,3 & 19,7 & 82,0 & 44,04 \\
$06 / 2002$ & 102,4 & 1,6 & 104,0 & 44,60 \\
\hline
\end{tabular}

${ }^{1}$ Desvio padrão do total de vassouras

A variação na quantidade de vassouras por planta, expressa pelos

valores de desvio padrão, deveu-se à escolha aleatória das plantas. Nessas plantas foi raro encontrar ramos sadios, ou seja, plantas maiores (com maior número de ramos) resultaram em maior quantidade de vassouras. A escolha aleatória das plantas independentemente do tamanho resultou na variação observada.

Os resultados obtidos na área considerada como fonte de inóculo estão de acordo com os obtidos em outras regiões com plantas suscetíveis. 
Cifuentes et al. (1982) encontraram incidências de aproximadamente 42,5 vassouras por planta na variedade "Crioulo" e 8,13 vassouras por planta em variedades híbridas. Almeida \& Andebrhan (1987) quantificaram 468 infecções (ramos e almofadas florais) por planta em cacaueiros com 8 a 10 anos de idade.

Rudgard (1987a) ao investigar a produção de vassouras em plantas híbridas suscetíveis (Catongo X UF613), com aproximadamente 10 anos de idade, encontrou 184 vassouras vegetativas em 1984. No ano seguinte, essas mesmas plantas apresentaram 618 vassouras novas.

Antes da instalação de um experimento para avaliar o efeito da poda fitossanitária e aplicação de fungicida, Almeida et al. (1998) encontraram nessa área uma incidência de 289,5 vassouras por cacaueiro.

\subsubsection{Incidência na área experimental}

As médias das contagens de vassouras vegetativas, nas safras principal e temporã, revelaram baixos valores (Tabela 4), quando comparadas às encontradas na área considerada como fonte de inóculo. $O$ mesmo pode ser dito quanto æ̀ contagens de frutos com vassoura e dos frutos que sofreram outros danos, em relação aos frutos sadios.

Tabela 4. Média das contagens por planta de vassouras vegetativas (VV), frutos com vassoura (FV), frutos sadios (FS) e frutos com outros danos (OD) nas safras principal e temporã

\begin{tabular}{ccccccc}
\hline Safra & Sub-área & Repetições & VV & FV & FS & OD \\
\hline Principal & & & & & & \\
& 1 & 278 & 0,91 & 0,68 & 1,97 & 0,31 \\
& 2 & 279 & 0,46 & 0,63 & 2,23 & 0,36 \\
Temporã & 3 & 281 & 0,09 & 0,17 & 4,08 & 0,33 \\
& 1 & 278 & 0,13 & 0,13 & 1,51 & 0,09 \\
& 2 & 279 & 0,07 & 0,20 & 1,13 & 0,13 \\
& 3 & 281 & 0,04 & 0,13 & 1,75 & 0,13 \\
\hline
\end{tabular}




\subsubsection{Infecção em ramos}

A lei exponencial foi utilizada em todas as análises por ter apresentado maior número de análises de variâncias significativas, quando comparada à lei potencial. Na safra principal houve formação de gradiente, porém devido à grande variação da incidência da doença ao longo das distâncias analisadas, coeficientes de determinação baixos foram obtidos (Tabela 5 e Figura 2). Na safra temporã, porém, as análises não foram significativas, demonstrando a ausência de gradiente (Tabela 6 e Figura 2).

Tabela 5. Resultado das análises de regressão das contagens de vassoura vegetativa, na safra principal, aplicando a lei exponencial

\begin{tabular}{ccccc}
\hline Sub-área & Inclinação (b) & Interseção $(\ln \mathrm{a})$ & $\mathrm{R}^{2}$ & $\mathrm{~F}^{1}$ \\
\hline 1 & $-0,0008$ & 0,6278 & 0,088 & $4,23^{*}$ \\
2 & $-0,001$ & 0,5209 & 0,228 & $12,96^{* *}$ \\
3 & $-0,0004$ & 0,1778 & 0,124 & $6,21^{*}$ \\
\hline${ }^{*}{ }^{* *}$ significante a $5 \%$ e a & $1 \%$ de probabilidade, respectivamente; ns, não \\
significativo
\end{tabular}

Tabela 6. Resultado das análises de regressão das contagens de vassoura vegetativa, na safra temporã, aplicando a lei exponencial

\begin{tabular}{ccccc}
\hline Sub-área & Inclinação (b) & Interseção $(\ln$ a) & $\mathrm{R}^{2}$ & $\mathrm{~F}^{1}$ \\
\hline 1 & 0,0003 & 0,0455 & 0,059 & $2,74 \mathrm{~ns}$ \\
2 & $-0,0003$ & 0,1141 & 0,080 & $3,82 \mathrm{~ns}$ \\
3 & $-0,0001$ & 0,0754 & 0,022 & $1,01 \mathrm{~ns}$ \\
\hline${ }^{*}{ }^{* *}$ significante a $5 \%$ e a & $1 \%$ de probabilidade, respectivamente; ns, não \\
significativo
\end{tabular}


Tabela 7. Resultado das análises de regressão das contagens de vassoura vegetativa, na safra principal, aplicando a lei exponencial, em quatro genótipos

\begin{tabular}{cccccr}
\hline Sub-área & Genótipo & Inclinação (b) & Interseção (In a) & $\mathrm{R}^{2}$ & $\mathrm{~F}^{1}$ \\
\hline 1 & & & & & \\
& NO-17 & $-0,0038$ & 1,3811 & 0,763 & $25,722^{* *}$ \\
& NO-24 & $-0,0021$ & 0,8514 & 0,265 & $4,32 \mathrm{~ns}$ \\
& NO-34 & $-0,0006$ & 0,3582 & 0,058 & $1,91 \mathrm{~ns}$ \\
2 & NO-42 & $-0,0021$ & 0,5563 & 0,161 & $2,11 \mathrm{~ns}$ \\
& & & & & \\
& NO-17 & $-0,0015$ & 0,3989 & 0,306 & $2,20 \mathrm{~ns}$ \\
& NO-24 & $-0,002$ & 0,7468 & 0,667 & $24,05{ }^{* *}$ \\
& NO-34 & $-0,0012$ & 0,2964 & 0,212 & $3,77 \mathrm{~ns}$ \\
3 & NO-42 & $-0,0001$ & 0,2194 & 0,006 & $0,15 \mathrm{~ns}$ \\
& & & & & \\
& NO-17 & $-0,0004$ & 0,1573 & 0,120 & $1,36 \mathrm{~ns}$ \\
& NO-24 & 0,0008 & 0,0642 & 0,027 & $0,17 \mathrm{~ns}$ \\
& NO-34 & 0,0001 & $-0,006$ & 0,042 & $0,66 \mathrm{~ns}$ \\
& NO-42 & $-0,0014$ & 0,2237 & 0,072 & $0,85 \mathrm{~ns}$ \\
\hline
\end{tabular}

$1{ }^{*},{ }^{* *}$ significante a $5 \%$ e a $1 \%$ de probabilidade, respectivamente; ns, não significativo

Tabela 8. Resultado das análises de regressão das contagens de vassoura vegetativa, na safra temporã, aplicando a lei exponencial, em quatro genótipos

\begin{tabular}{cccccc}
\hline Sub-área & Genótipo & Inclinação (b) & Interseção $(\ln \mathrm{a})$ & $\mathrm{R}^{2}$ & $\mathrm{~F}^{1}$ \\
\hline 1 & & & & & \\
& NO-17 & 0,0002 & 0,0349 & 0,015 & $0,12 \mathrm{~ns}$ \\
& NO-24 & $-0,0002$ & 0,0989 & 0,115 & $1,55 \mathrm{~ns}$ \\
& NO-34 & 0,0001 & 0,0148 & 0,019 & $0,59 \mathrm{~ns}$ \\
& NO-42 & $-0,0005$ & 0,0928 & 0,144 & $1,86 \mathrm{~ns}$ \\
& & & & & \\
& NO-17 & $-0,0023$ & 0,5935 & 0,591 & $7,22{ }^{*}$ \\
& NO-24 & $-0,0001$ & 0,0538 & 0,128 & $1,77 \mathrm{~ns}$ \\
& NO-34 & $-2 \mathrm{E}-05$ & 0,0285 & 0,000 & $0,01 \mathrm{~ns}$ \\
& NO-42 & $-0,0001$ & 0,0691 & 0,038 & $1,04 \mathrm{~ns}$ \\
& & & & & \\
& NO-17 & $-8 \mathrm{E}-05$ & 0,055 & 0,006 & $0,06 \mathrm{~ns}$ \\
& NO-24 & $-0,0011$ & 0,1354 & 0,027 & $0,17 \mathrm{~ns}$ \\
& NO-34 & 0,0002 & $-0,0109$ & 0,042 & $0,66 \mathrm{~ns}$ \\
& NO-42 & 0,0018 & $-0,0731$ & 0,133 & $1,69 \mathrm{~ns}$ \\
\hline
\end{tabular}

$1{ }^{*},{ }^{* *}$ significante a $5 \%$ e a $1 \%$ de probabilidade, respectivamente; ns, não significativo 
Safra principal
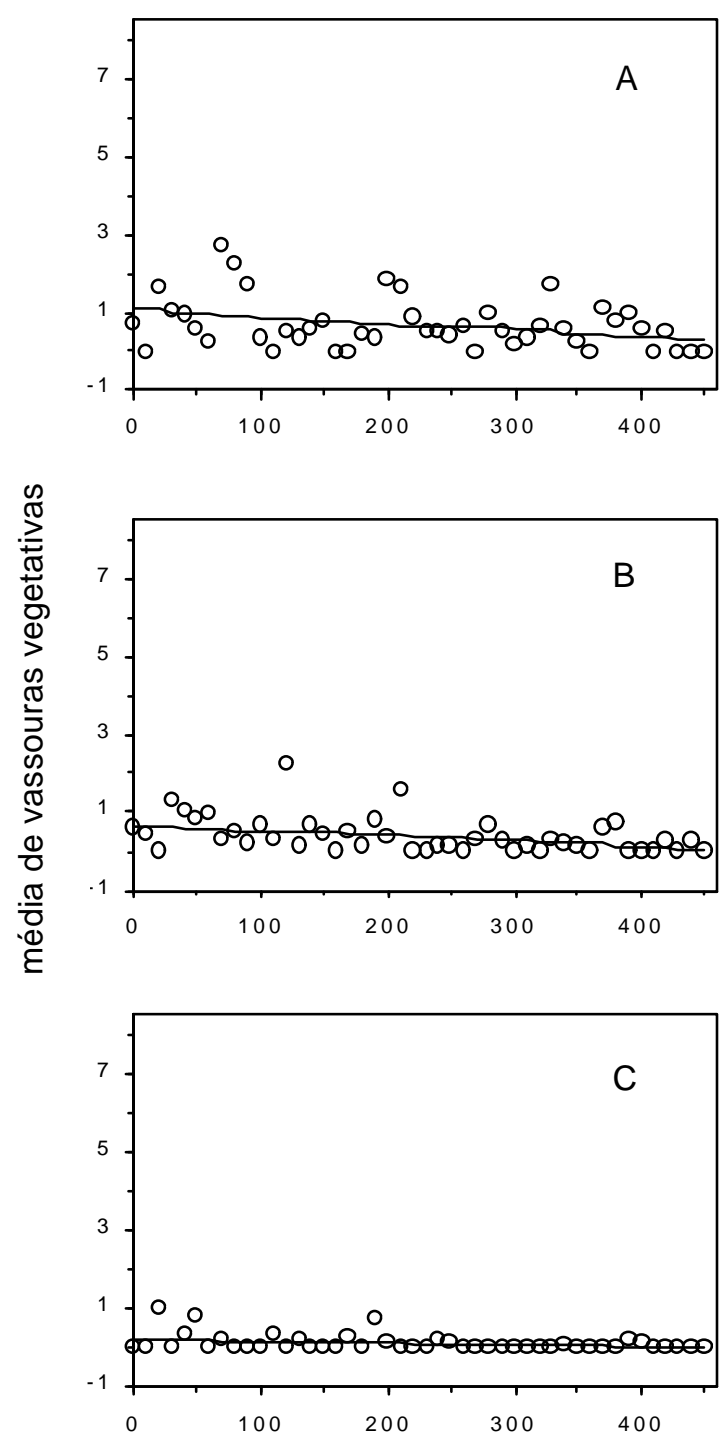

Safra temporã
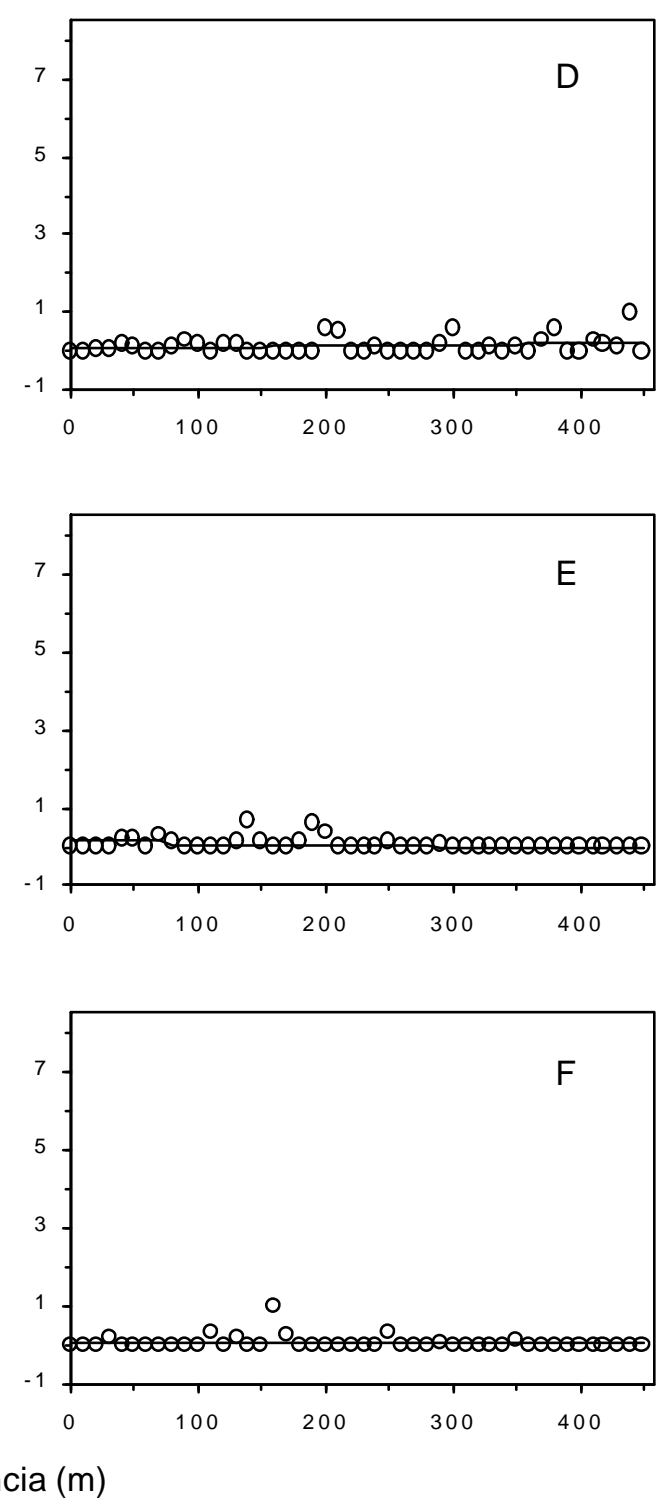

Figura 2 - Gradientes de vassoura-de-bruxa do cacaueiro, quantificados em vassouras vegetativas, em todos os genótipos. Na safra principal, sub-área $1(\mathrm{~A})$, sub-área $2(\mathrm{~B})$ e sub-área $3(\mathrm{C})$. Na safra temporã, sub-área $1(D)$, sub-área $2(E)$ e sub-área $3(F)$. 
Safra principal
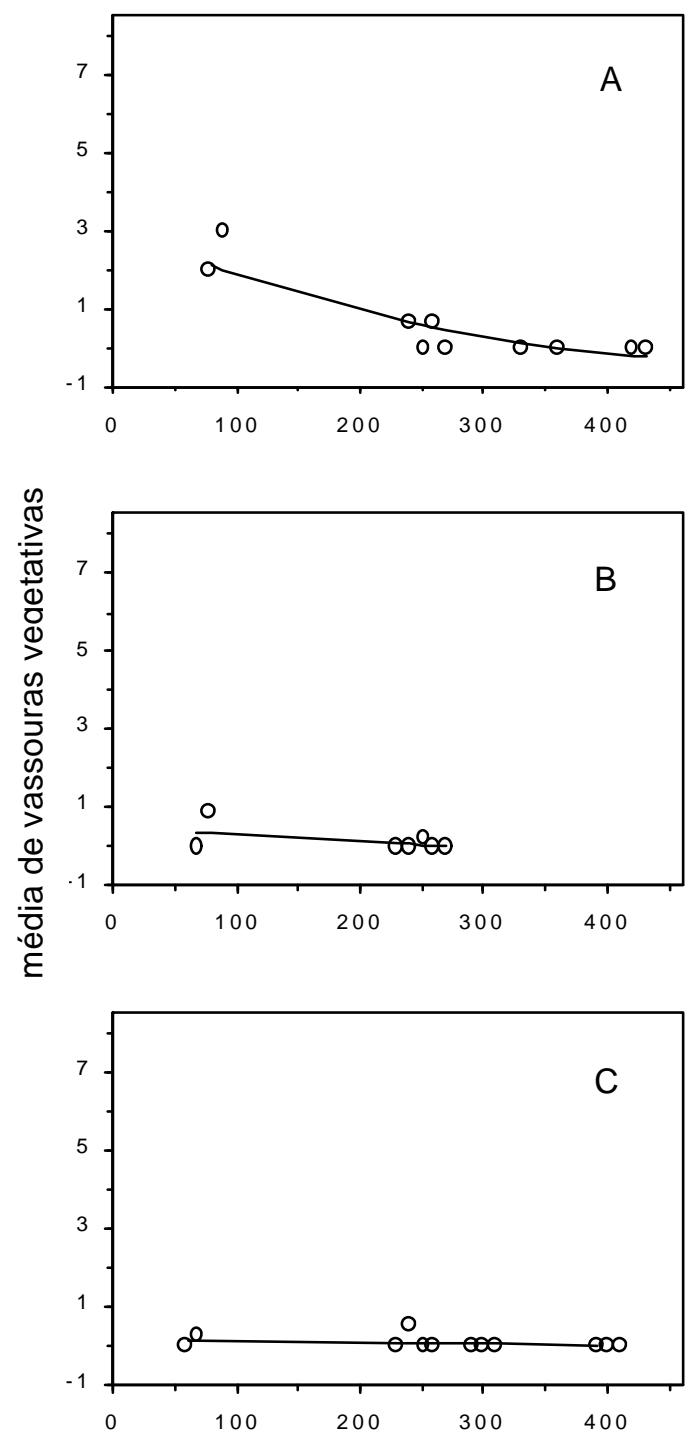

Safra temporãı
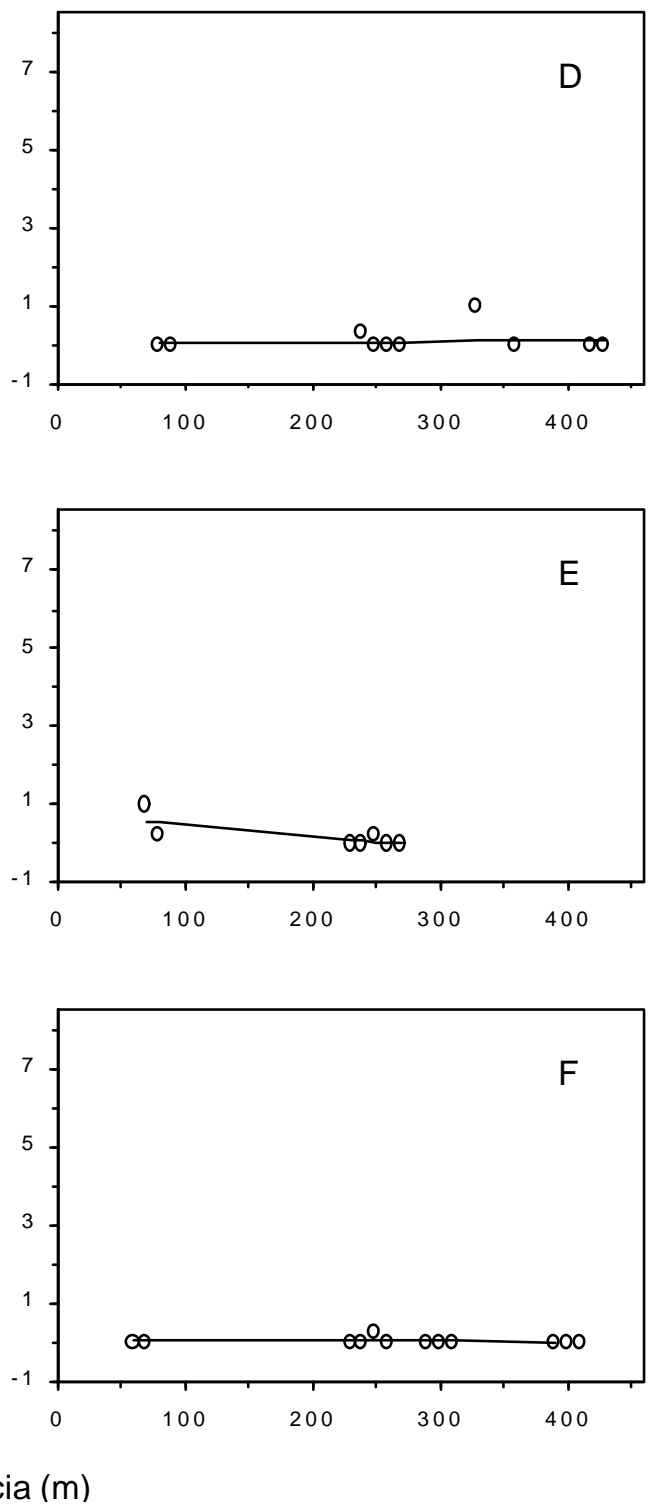

Figura 3 - Gradientes de vassoura-de-bruxa do cacaueiro, quantificados em vassouras vegetativas, no genótipo NO-17. Na safra principal, subárea $1(A)$, sub-área 2 (B) e sub-área 3 (C). Na safra temporã, subárea 1(D), sub-área $2(\mathrm{E})$ e sub-área $3(\mathrm{~F})$. 
Safra principal
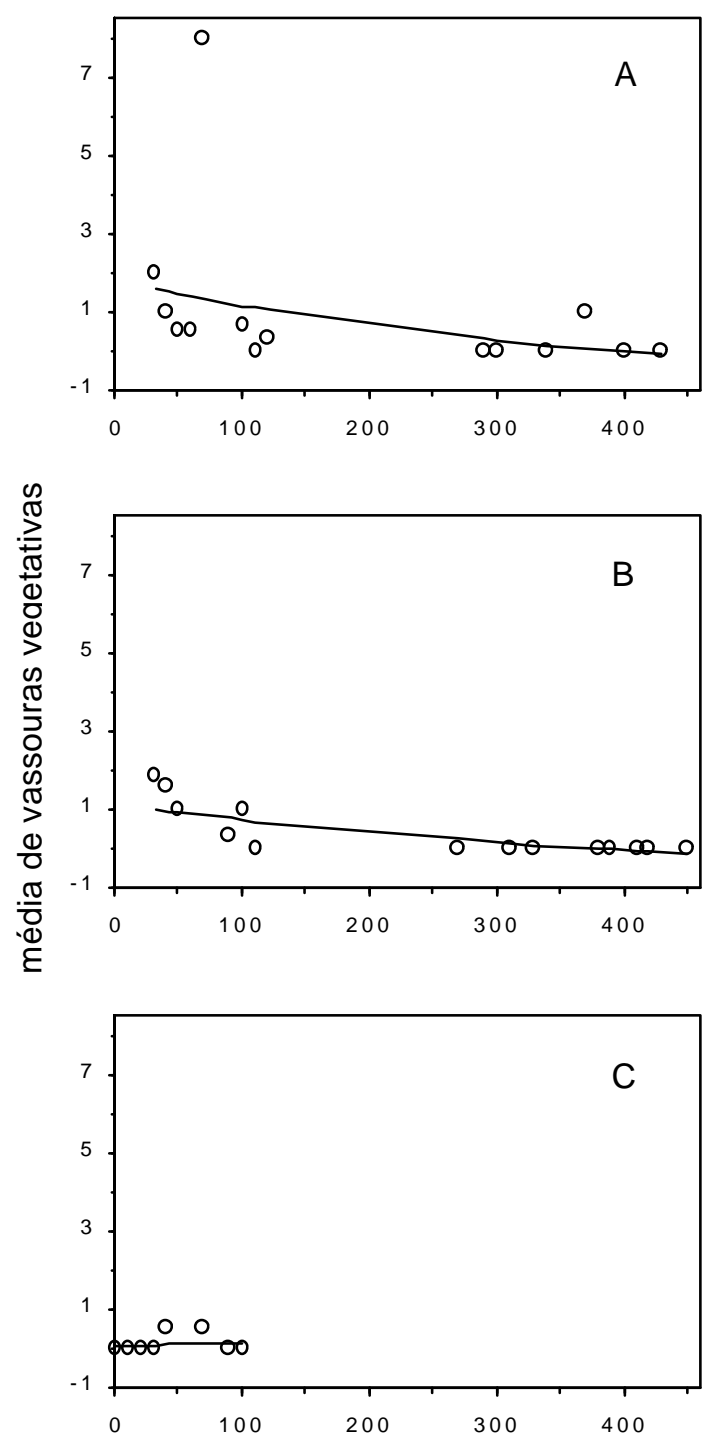

Safra temporã
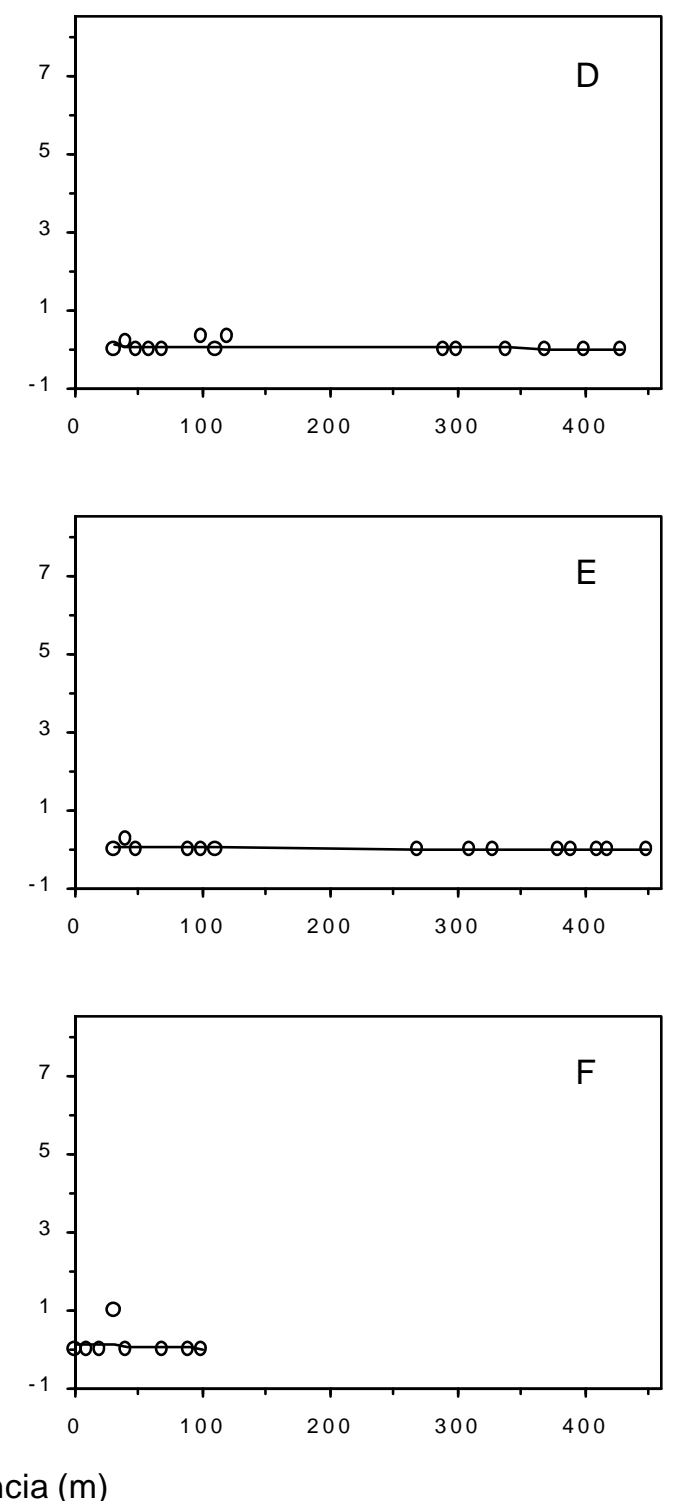

Figura 4 - Gradientes de vassoura-de-bruxa do cacaueiro, quantificados em vassouras vegetativas, no genótipo NO-24. Na safra principal, subárea $1(A)$, sub-área $2(B)$ e sub-área $3(C)$. Na safra temporã, subárea 1(D), sub-área $2(\mathrm{E})$ e sub-área $3(\mathrm{~F})$. 
Safra principal
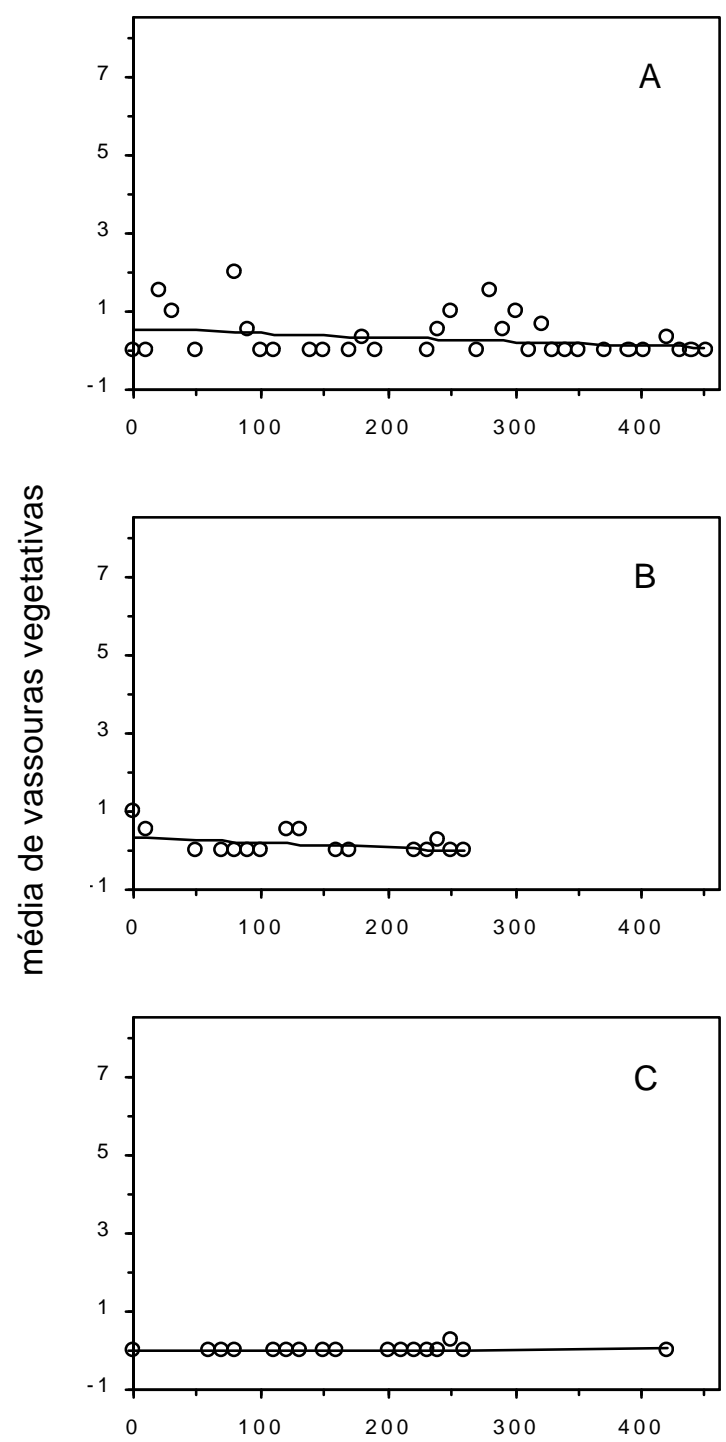

Safra temporãı
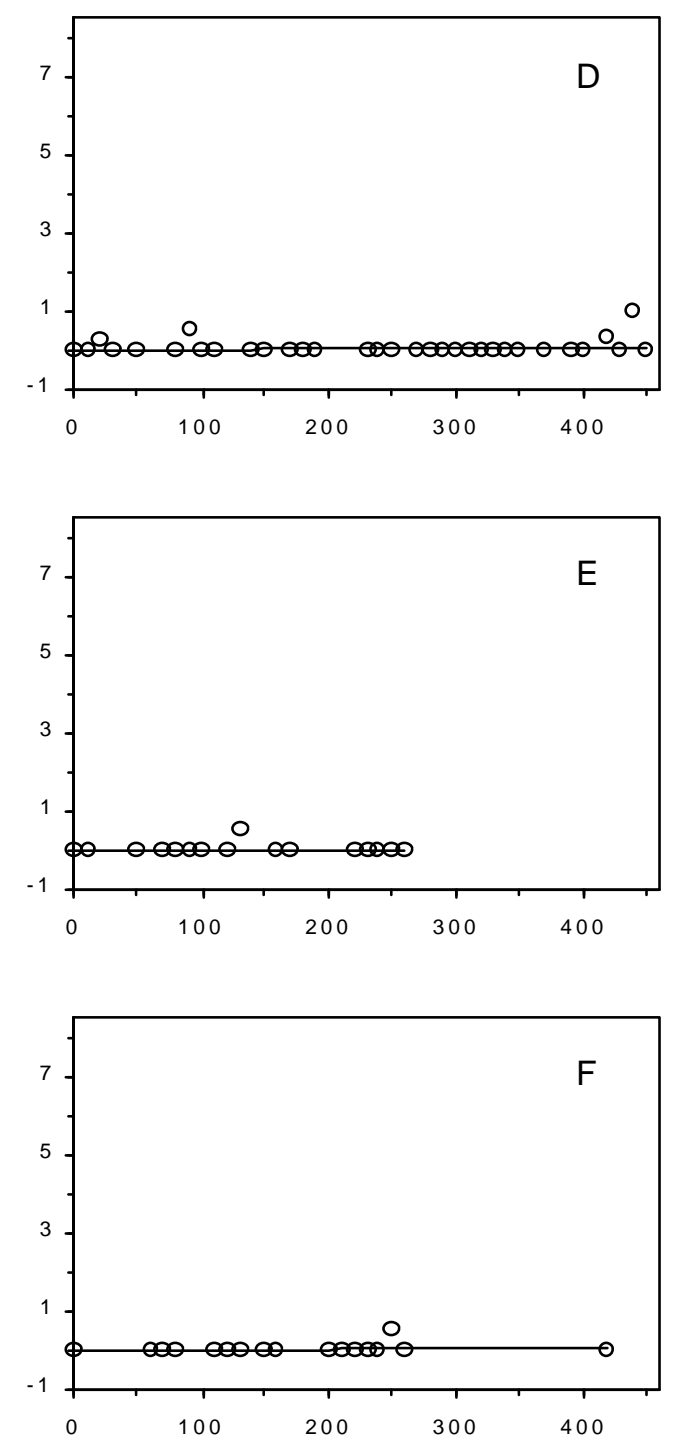

Distância (m)

Figura 5 - Gradientes de vassoura-de-bruxa do cacaueiro, quantificados em vassouras vegetativas, no genótipo NO-34. Na safra principal, subárea $1(A)$, sub-área $2(B)$ e sub-área $3(C)$. Na safra temporã, subárea 1(D), sub-área $2(\mathrm{E})$ e sub-área $3(\mathrm{~F})$. 
Safra principal

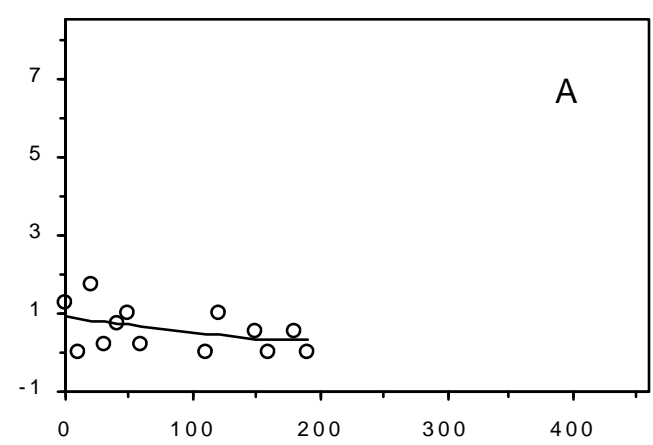

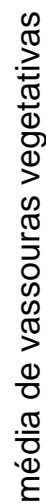

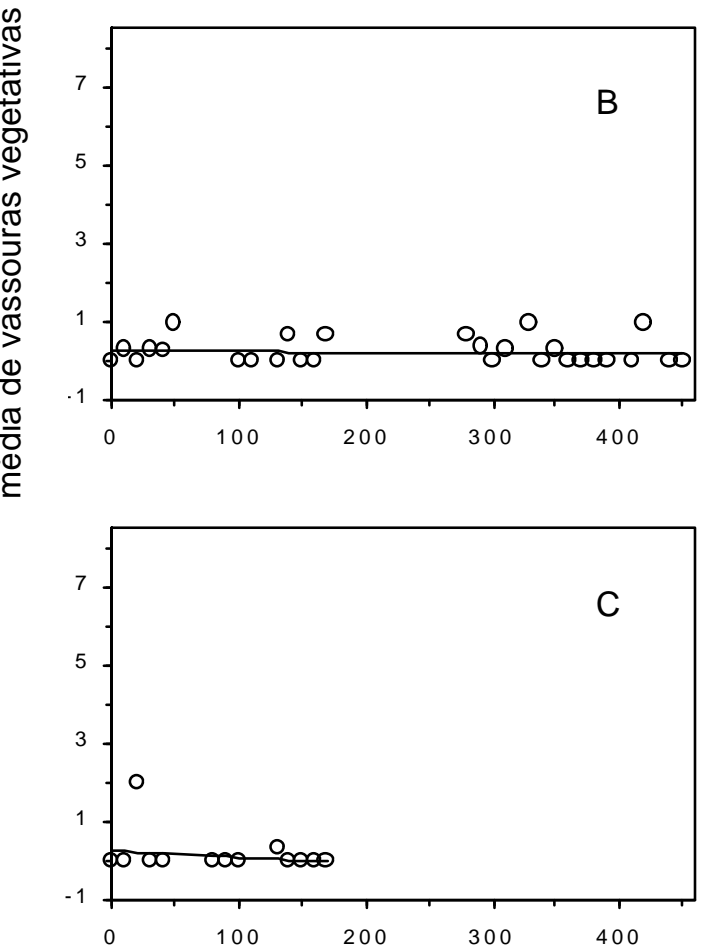

Safra temporãı
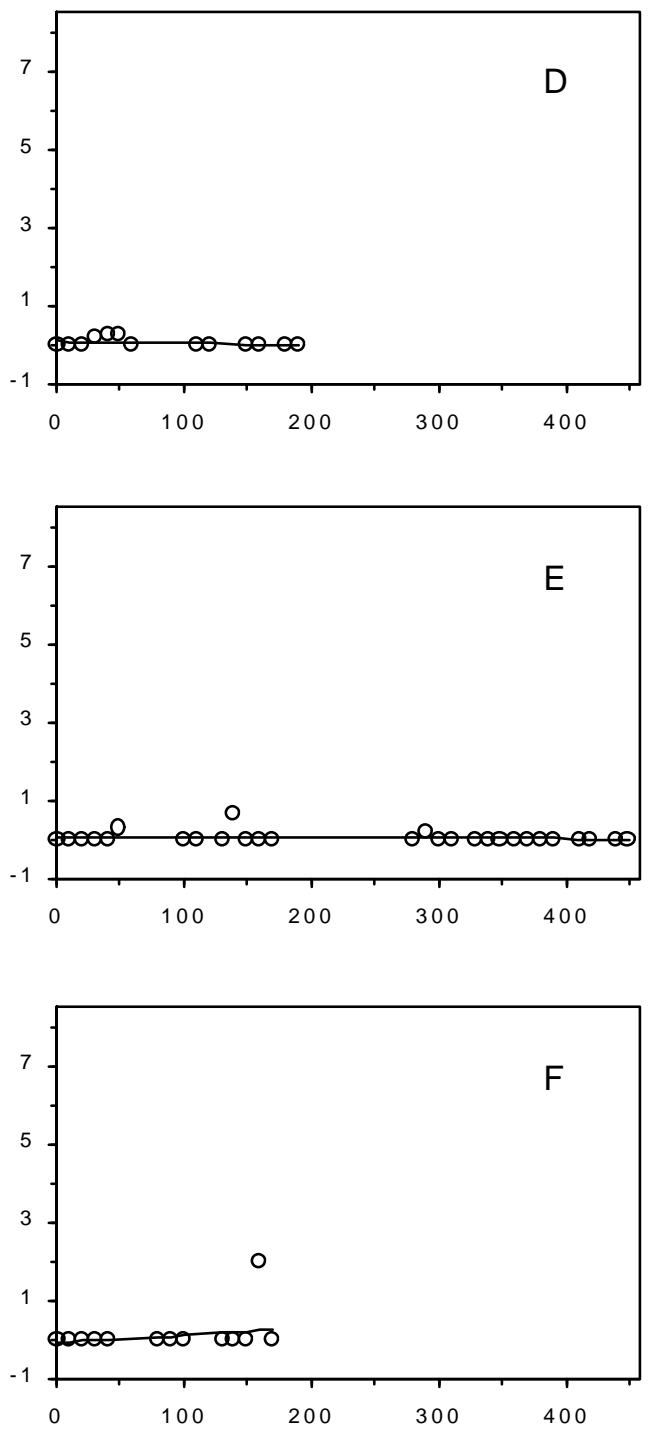

Distância (m)

Figura 6 - Gradientes de vassoura-de-bruxa do cacaueiro, quantificados em vassouras vegetativas, no genótipo NO-42. Na safra principal, subárea $1(A)$, sub-área 2 (B) e sub-área 3 (C). Na safra temporã, subárea 1(D), sub-área $2(\mathrm{E})$ e sub-área $3(\mathrm{~F})$. 
Os valores de inclinação obtidos revelaram pequena taxa de diminuição da incidência com o aumento da distância. Embora tenham sido significativas as análises de variância na safra principal, os coeficientes de determinação foram baixos.

Utilizando-se também a lei exponencial houve ausência de gradiente para a maioria das regressões realizadas nos quatro genótipos mais abundantes, nas duas safras (Tabelas 7 e 8; Figuras 3, 4, 5 e 6).

De forma geral, a safra temporã apresentou menor nível de doença, comparada à safra principal. Apenas o genótipo NO-24, na sub-área 2, safra principal, e o genótipo NO-17, na sub-área 2, safra temporã, apresentaram gradiente significativo.

\subsubsection{Infecção em frutos}

A utilização de todas as plantas de cada sub-área, independentemente do genótipo, não revelou de forma conclusiva se há gradiente, quando analisada a incidência da doença em frutos (Tabelas 9 e 10).

Embora tenha sido significativa a análise de variância na sub-área 1 na safra principal, e nas sub-áreas 2 e 3 na safra temporã, pode-se observar que os valores dos coeficientes de determinação foram baixos. Ademais, o coeficiente angular na sub-área 1 , safra principal, foi positivo. $O$ baixo ajuste da reta aos dados foi devido à grande variação nos níveis de infecção nas distâncias avaliadas (Figura 7). 
Tabela 9. Resultado das análises de regressão das contagens de frutos infectados com vassoura-de-bruxa, na safra principal, aplicando a lei exponencial

\begin{tabular}{ccccc}
\hline Sub-área & Inclinação (b) & Interseção $(\ln$ a) & $\mathrm{R}^{2}$ & $\mathrm{~F}^{1}$ \\
\hline 1 & 0,0008 & 0,3085 & 0,095 & $4,611^{*}$ \\
2 & 0,0004 & 0,3744 & 0,021 & 0,96 ns \\
3 & $-8 \mathrm{E}-05$ & 0,1616 & 0,003 & 0,14 ns \\
\hline${ }^{*{ }^{*},{ }^{* *}}$ significante & a $5 \%$ e a & $1 \%$ & de probabilidade, & respectivamente; ns, não \\
significativo
\end{tabular}

Tabela 10. Resultado das análises de regressão das contagens de frutos infectados com vassoura-de-bruxa, na safra temporã, aplicando a lei exponencial

\begin{tabular}{ccccc}
\hline Sub-área & Inclinação (b) & Interseção $(\operatorname{In} \mathrm{a})$ & $\mathrm{R}^{2}$ & $\mathrm{~F}^{1}$ \\
\hline 1 & $5 \mathrm{E}-05$ & 0,1051 & 0,002 & $0,07 \mathrm{~ns}$ \\
2 & $-0,0006$ & 0,2727 & 0,198 & $10,84^{* *}$ \\
3 & $-0,0005$ & 0,2177 & 0,125 & $6,28^{*}$ \\
\hline
\end{tabular}

${ }_{1}{ }^{*},{ }^{* *}$ significante a $5 \%$ e a $1 \%$ de probabilidade, respectivamente; ns, não significativo

Semelhantemente ao que foi realizado com os dados de vassouras vegetativas, os dados de frutos com vassoura, dos quatro genótipos mais abundantes, foram submetidos ao ajuste de gradiente pela lei exponencial (Tabelas 11 e 12; Figuras 8, 9, 10 e 11).

$\mathrm{Na}$ safra principal, somente o genótipo NO-34, na sub-área 1, apresentou gradiente significativo. Na safra temporã, apenas o genótipo NO-34, na sub-área 2, e o genótipo NO-42, na sub-área 3, apresentaram gradiente significativo. 
Tabela 11. Resultado das análises de regressão das contagens de frutos infectados com vassoura-de-bruxa, na safra principal, aplicando a lei exponencial, em quatro genótipos

\begin{tabular}{cccccc}
\hline Sub-área & Genótipo & Inclinação (b) & Interseção (In a) & $\mathrm{R}^{2}$ & $\mathrm{~F}^{1}$ \\
\hline 1 & & & & & \\
& NO-17 & 0,0012 & 0,3125 & 0,068 & $0,59 \mathrm{~ns}$ \\
& NO-24 & $-0,0021$ & 0,8858 & 0,298 & $5,09{ }^{*}$ \\
& NO-34 & 0,0013 & 0,0427 & 0,161 & $5,944^{*}$ \\
& NO-42 & $-0,0003$ & 0,3652 & 0,003 & $0,03 \mathrm{~ns}$ \\
& & & & & \\
& NO-17 & $-0,0014$ & 0,3466 & 0,375 & $3,00 \mathrm{~ns}$ \\
& NO-24 & 0,0016 & 0,2414 & 0,246 & $3,91 \mathrm{~ns}$ \\
& NO-34 & $-0,0012$ & 0,3643 & 0,099 & $1,53 \mathrm{~ns}$ \\
3 & NO-42 & 0,001 & 0,0248 & 0,151 & $4,622^{*}$ \\
& NO-17 & 0,0001 & 0,0645 & 0,003 & $0,03 \mathrm{~ns}$ \\
& NO-24 & $-0,0053$ & 0,5766 & 0,159 & $1,14 \mathrm{~ns}$ \\
& NO-34 & 0,0012 & $-0,1528$ & 0,477 & $13,67{ }^{* *}$ \\
& NO-42 & $-0,0002$ & 0,0286 & 0,178 & $2,37 \mathrm{~ns}$ \\
\hline
\end{tabular}

$1{ }^{*},{ }^{* *}$ significante a $5 \%$ e a $1 \%$ de probabilidade, respectivamente; ns, não significativo

Tabela 12. Resultado das análises de regressão das contagens de frutos infectados com vassoura-de-bruxa, na safra temporã, aplicando a lei exponencial, em quatro genótipos

\begin{tabular}{|c|c|c|c|c|c|}
\hline Sub-área & Genótipo & Inclinação (b) & Interseção (In a) & $\mathrm{R}^{2}$ & $F^{1}$ \\
\hline \multicolumn{6}{|l|}{1} \\
\hline & NO-17 & $-3 E-05$ & 0,0366 & 0,001 & $0,01 \mathrm{~ns}$ \\
\hline & NO-24 & $-0,0006$ & 0,2011 & 0,208 & $3,15 \mathrm{~ns}$ \\
\hline & NO-34 & $-0,0001$ & 0,0805 & 0,019 & $0,59 \mathrm{~ns}$ \\
\hline & NO-42 & 0,0002 & 0,0299 & 0,016 & $0,18 \mathrm{~ns}$ \\
\hline \multicolumn{6}{|r|}{ 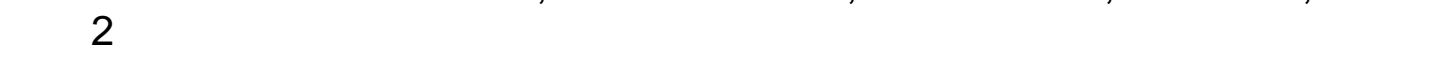 } \\
\hline & NO-17 & 0,0014 & $-0,033$ & 0,094 & $0,52 \mathrm{~ns}$ \\
\hline & NO-24 & $-0,0004$ & 0,2147 & 0,049 & $0,62 \mathrm{~ns}$ \\
\hline & NO-34 & $-0,0011$ & 0,2091 & 0,284 & $5,56 *$ \\
\hline & NO-42 & $-0,0004$ & 0,272 & 0,028 & $0,73 \mathrm{~ns}$ \\
\hline \multicolumn{6}{|r|}{. } \\
\hline & NO-24 & $\begin{array}{c}-0.0079 \\
-\end{array}$ & 0,0956 & $\begin{array}{r}0,315 \\
0 .-00\end{array}$ & $\begin{array}{r}2,76 \mathrm{~ns}\end{array}$ \\
\hline & NO-34 & 0,00 & 0,00 & - & - \\
\hline & NO-42 & $-0,0019$ & 0,2615 & 0,321 & $5,21 *$ \\
\hline
\end{tabular}


Safra principal
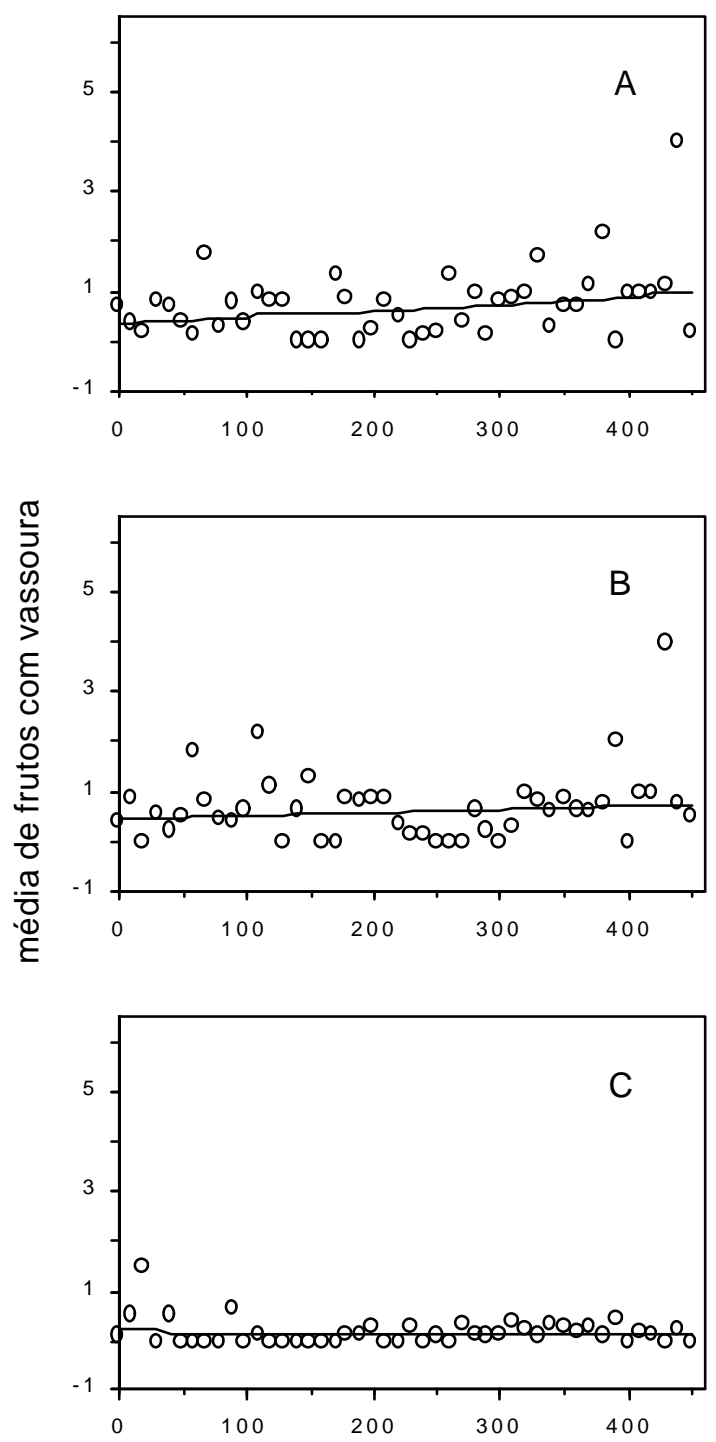

Safra temporã
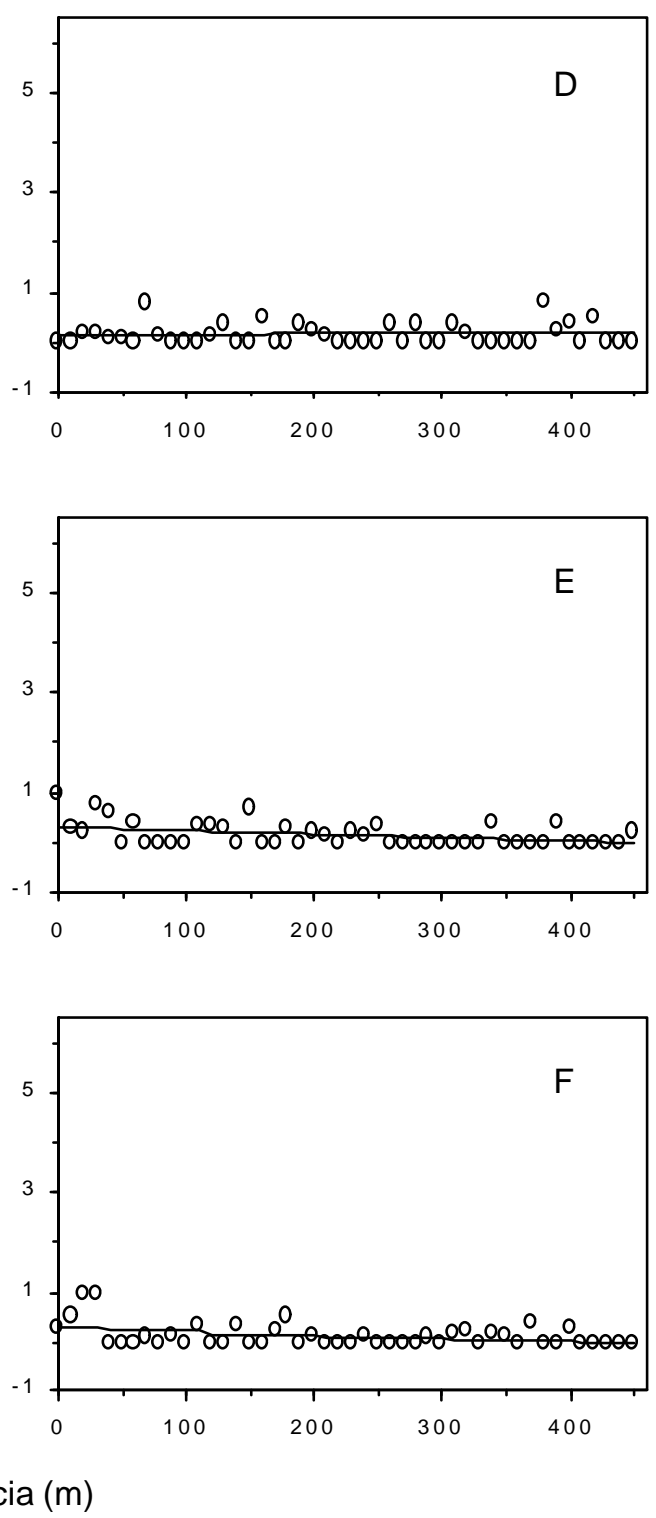

Figura 7 - Gradientes de vassoura-de-bruxa do cacaueiro, quantificados em frutos com vassoura, em todos os genótipos. Na safra principal, sub-área 1(A), sub-área 2 (B) e sub-área $3(C)$. Na safra temporã, sub-área $1(D)$, sub-área $2(E)$ e sub-área $3(F)$. 
Safra principal
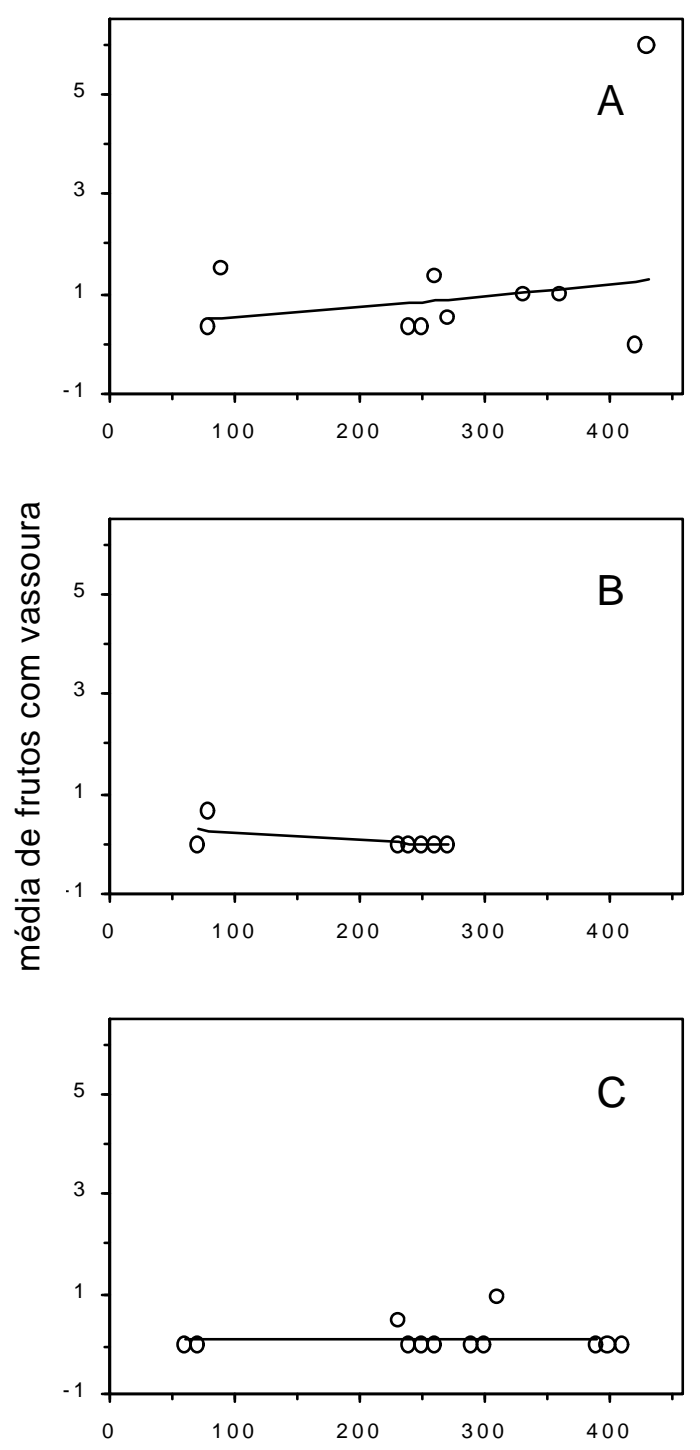

Safra temporãı
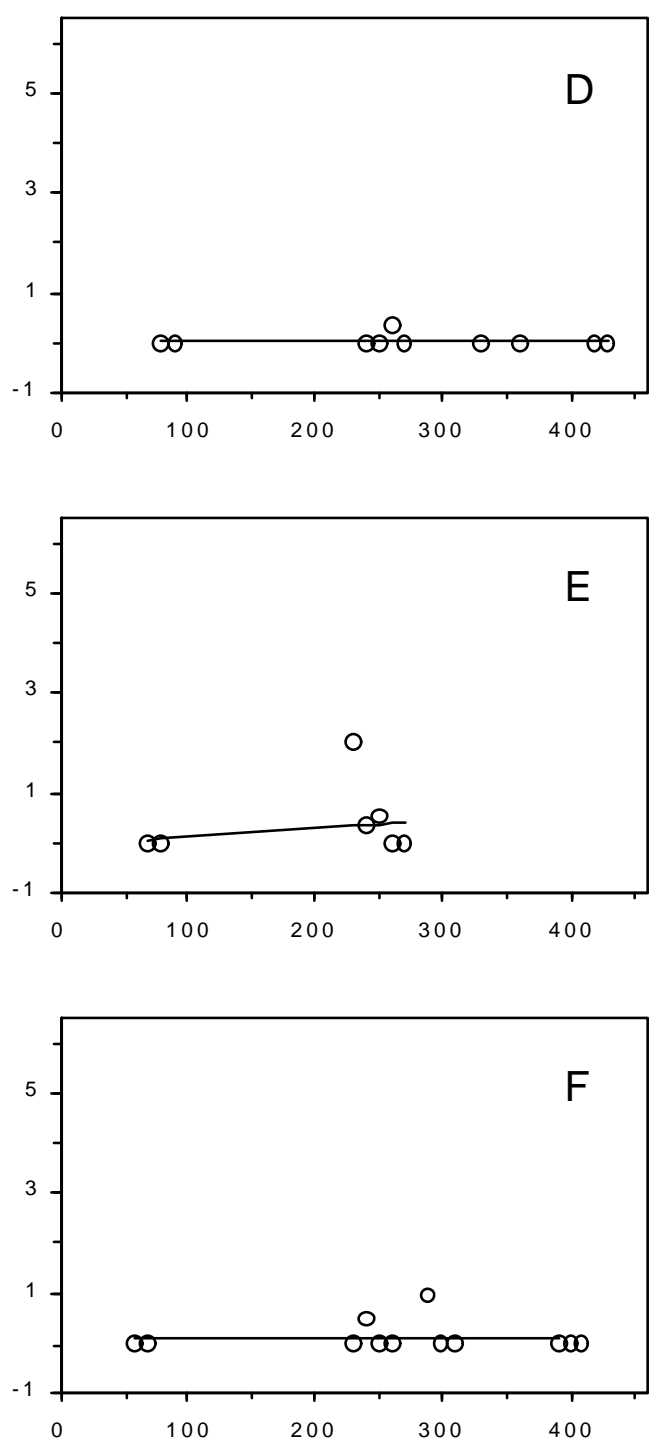

Distância (m)

Figura 8 - Gradientes de vassoura-de-bruxa do cacaueiro, quantificados em frutos com vassoura, no genótipo NO-17. Na safra principal, subárea $1(A)$, sub-área 2 (B) e sub-área $3(C)$. Na safra temporã, subárea 1(D), sub-área $2(\mathrm{E})$ e sub-área $3(\mathrm{~F})$. 
Safra principal
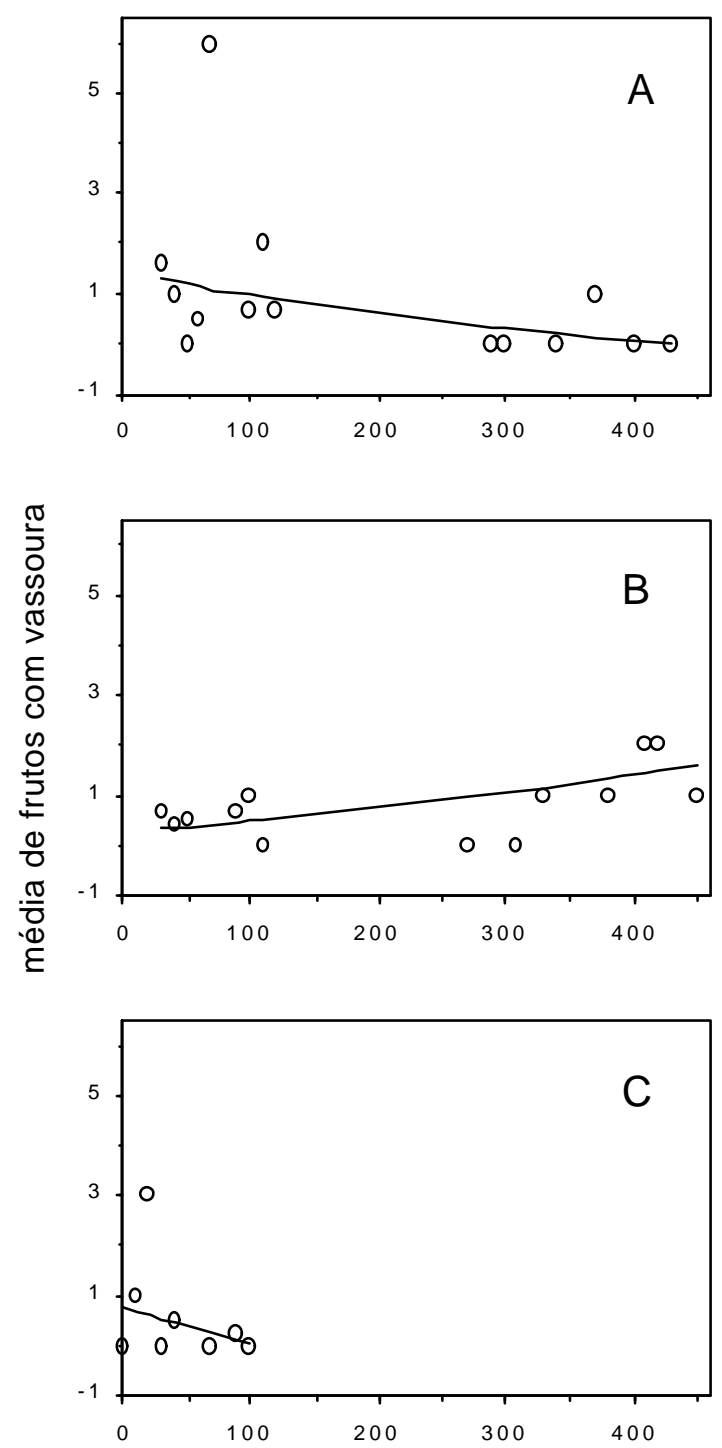

Safra temporãı
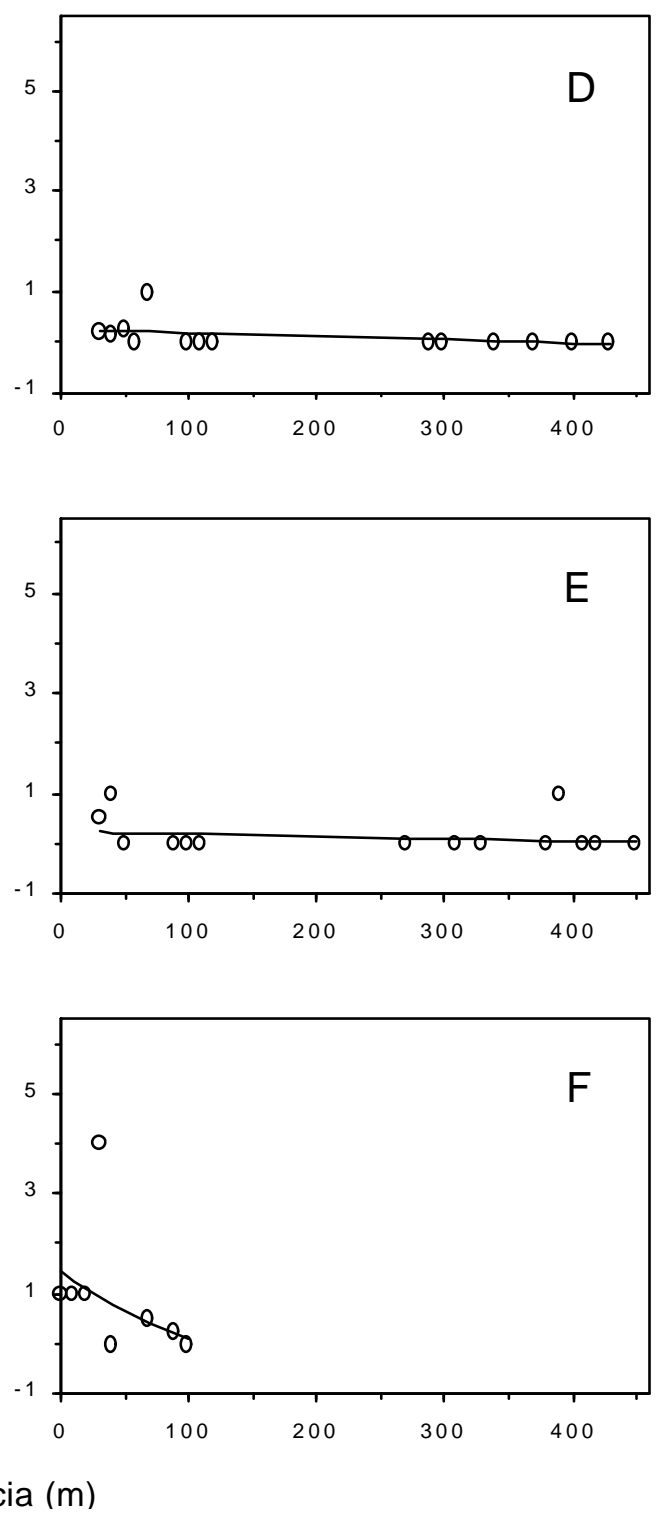

Figura 9 - Gradientes de vassoura-de-bruxa do cacaueiro, quantificados em frutos com vassoura, no genótipo NO-24. Na safra principal, subárea 1(A), sub-área 2 (B) e sub-área $3(\mathrm{C})$. Na safra temporã, subárea 1(D), sub-área $2(E)$ e sub-área $3(F)$. 
Safra principal
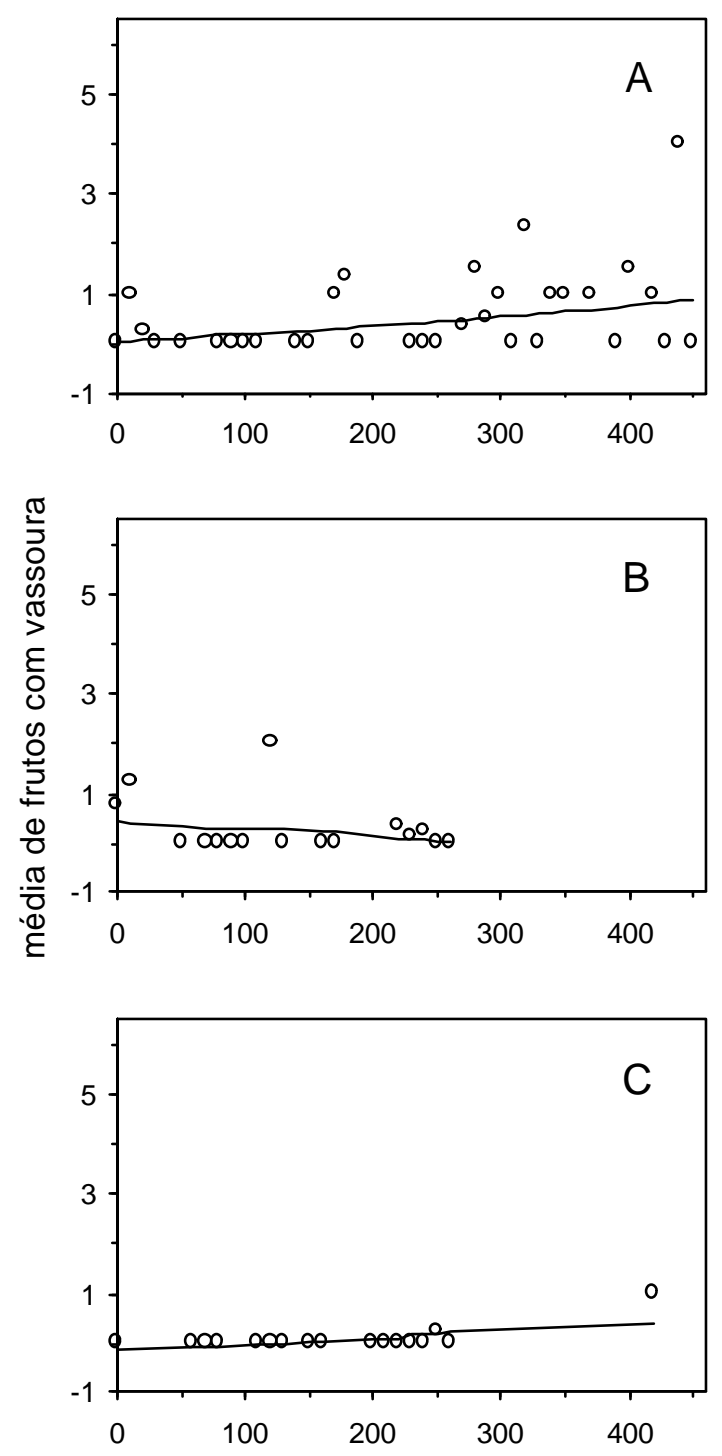

Safra temporã
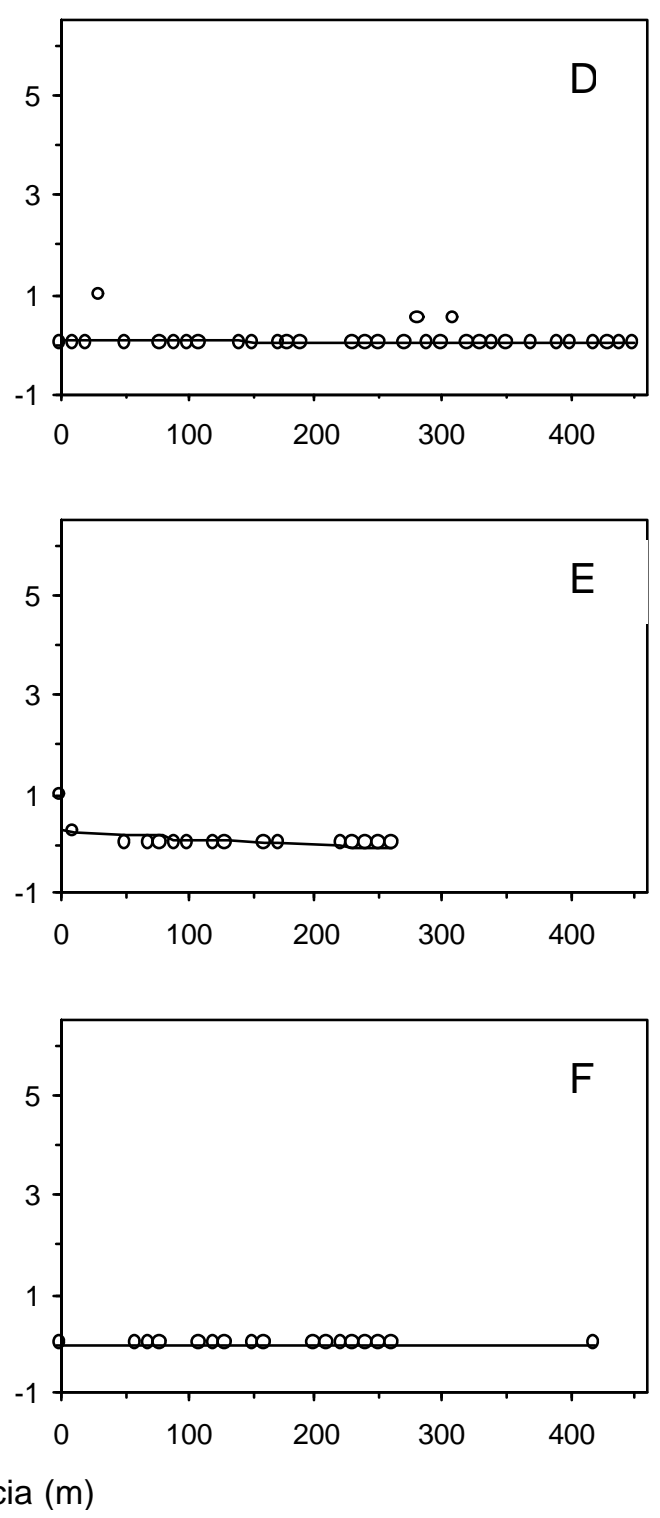

Figura 10 - Gradientes de vassoura-de-bruxa do cacaueiro, quantificados em frutos com vassoura, no genótipo NO-34. Na safra principal, subárea $1(A)$, sub-área $2(B)$ e sub-área $3(C)$. Na safra temporã, subárea 1(D), sub-área $2(\mathrm{E})$ e sub-área $3(\mathrm{~F})$. 
Safra principal
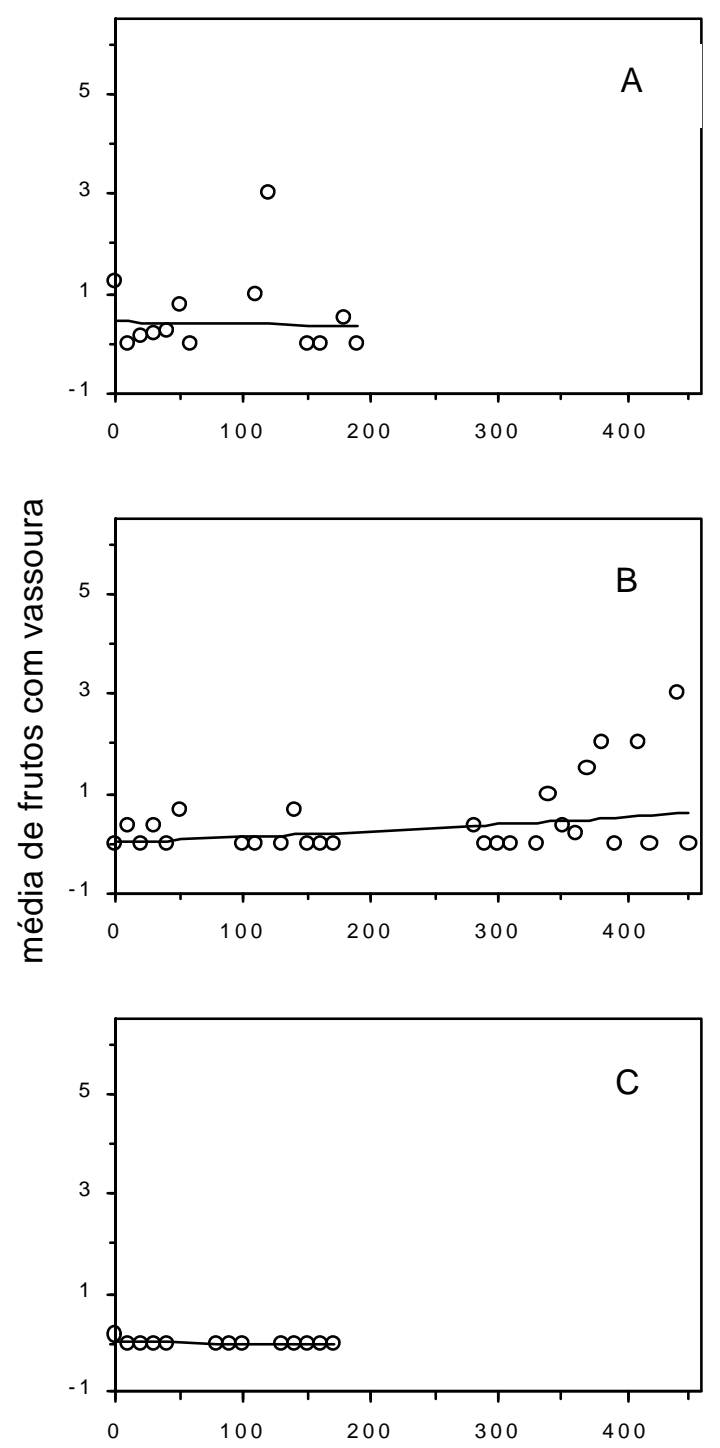

Safra temporãı
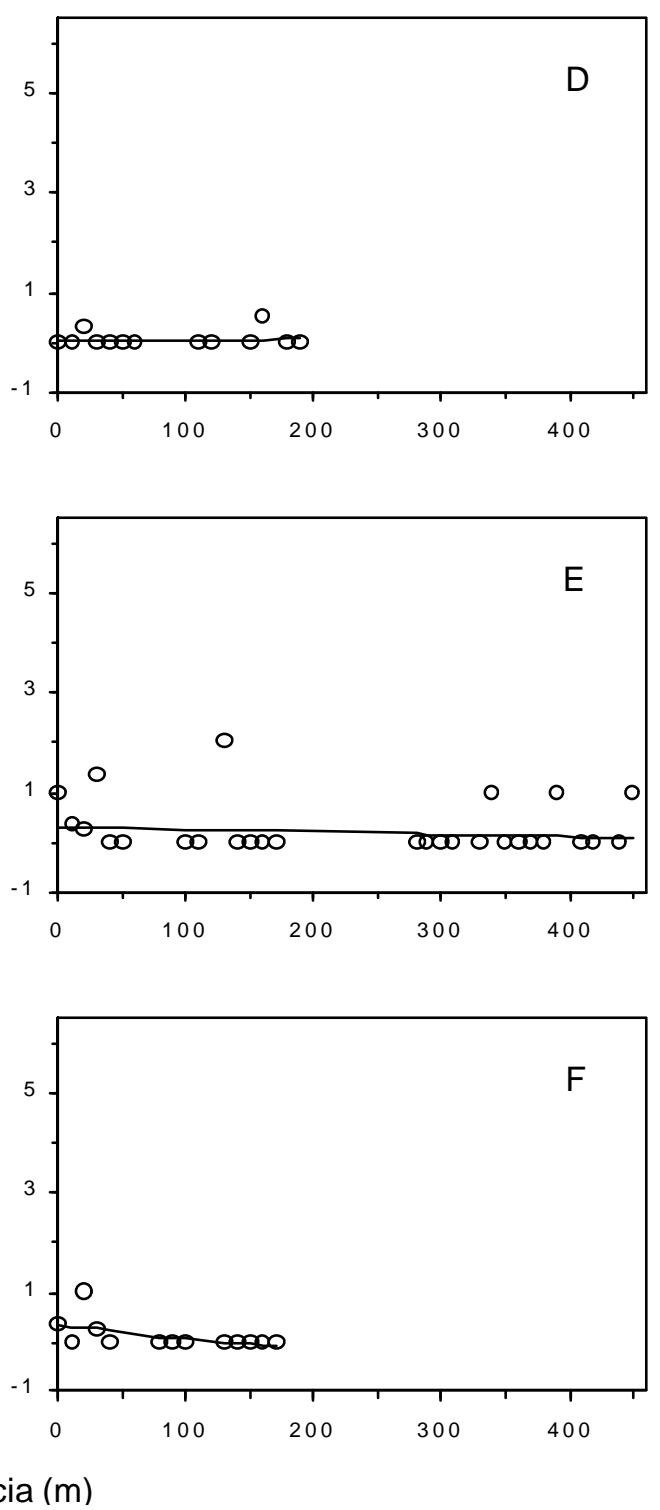

Figura 11 - Gradientes de vassoura-de-bruxa do cacaueiro, quantificados em frutos com vassoura, no genótipo NO-42. Na safra principal, subárea $1(A)$, sub-área 2 (B) e sub-área $3(C)$. Na safra temporã, subárea 1(D), sub-área $2(\mathrm{E})$ e sub-área $3(\mathrm{~F})$. 
Baker et al. (1941) foram os primeiros a registrar diminuição do número de vassouras por planta com o aumento da distância de uma área sem poda fitossanitária. A área experimental foi dividida em 36 parcelas de 16 plantas cada, com seis genótipos diferentes (ICS 1, 7, 16, 22, 45 e 53). Nessa área havia cacaueiros jovens, de dois e três anos de idade. Adjacente a essa área havia cacaueiros com alta incidência da doença. Os genótipos apresentaram uma incidência de, aproximadamente, 5,5 vassouras/planta, não havendo diferença significativa entre eles. Apenas houve diferença no total de vassouras produzidas, que diminuiu com o aumento da distância da área adjacente com alta incidência da doença.

Embora o experimento da fazenda Novo Oriente também tenha sido realizada com uma mistura de genótipos e com dois e três anos de idade, a média de vassouras produzida por planta foi muito menor $(0,61$ vassouras/planta). Isso indica que as plantas utilizadas por Baker et al. (1941) eram mais suscetíveis e as da fazenda Novo Oriente mais resistentes.

Os primeiros trabalhos que tiveram a preocupação de analisar o gradiente em almofadas florais e frutos, além de vassouras vegetativas, foram os relatados por Maddison et al. (1993a), com protocolos semelhantes em dois locais no Brasil, dois locais da Colômbia, um no Equador e um na Venezuela. Nesses trabalhos foram utilizados dentro da mesma área 10 linhas como fonte de inóculo e 35 linhas para quantificação do gradiente. Desses locais, em quatro foram significativas as análises de variância em vassouras vegetativas, com valores de inclinação variando de $-0,1022$ a $-0,0174$ e coeficientes de determinação variando de 0,44 a 0,82. Em frutos, três locais apresentaram análises de variância significativas, variando de $-0,0009$ a $-0,0089$ os valores de inclinação e de 0,12 a 0,49 os valores dos coeficientes de determinação.

Comparando-se os resultados de Maddison et al. (1993a) aos do presente trabalho, pode-se observar que este apresenta valores de inclinação menores, tanto em vassouras vegetativas como em frutos com vassoura. A metodologia aqui utilizada para detecção do gradiente objetivou constatar o que 
realmente acontece no campo, sem quaisquer manipulações que poderiam favorecer o patógeno, diferentemente do que é utilizado quando se objetiva analisar o gradiente em mudas. Aragundi et al. (1987) e Rudgard (1987a) obtiveram gradientes com inclinações maiores com o uso de mudas suscetíveis àdoença.

A inexistência de um gradiente de doença claro neste trabalho, aliado à detecção da doença em toda a área experimental, indica que basidiósporos do patógeno encontram-se presentes de forma generalizada na região, o que dificulta e pode inviabilizar tratamentos fitossanitários em propriedades isoladas.

Todas as vassouras produzidas na área experimental foram retiradas, não havendo, portanto, a possibilidade do inóculo ter sido produzido dentro da área. Certamente os ramos e frutos que se apresentaram doentes foram infectados com inóculo produzido em outra área. Evans \& Solorzano (1982), ao obterem mudas infectadas com vassoura-de-bruxa em área isolada cerca de $800 \mathrm{~m}$ de outras plantações de cacau, demonstraram que o patógeno poderia se disseminar por mais de $800 \mathrm{~m}$.

Em Palma Cháves, Equador, houve um registro de $8 \%$ de frutos doentes e de 40 vassouras por árvore, mesmo após cuidadosa retirada das vassouras de toda a plantação. $O$ autor presumiu que a maior parte dessa incidência foi devido a inóculo vindo de outras plantações (Maddison et al., 1993a). Segundo Tollenaar (1959) não há evidências que a remoção de vassouras implique na redução de frutos doentes devido à vassoura-de-bruxa, pois níveis de até $80 \%$ foram constatados na época chuvosa.

Maddison et al. (1993a), ao comparar os gradientes obtidos em três tecidos diferentes (almofadas florais, ramos e frutos), revelou que eles diferem para um mesmo local, afirmando que uma distância que proporciona baixas infecções em almofadas florais poderia não ser suficiente para reduzir igualmente a incidência em ramos e frutos. As causas para que haja essa 
diferença não são conhecidas. O mesmo autor afirma que poderia ser resultado de diferenças no período de suscetibilidade dos tecidos.

Os ramos possuem um período de suscetibilidade mais curto, sendo que as gemas ativas são bastante suscetíveis e àmedida que a brotação de desenvolve a infecção se torna mais difícil, não ocorrendo a infecção em folhas maduras (Baker \& Crowdy, 1943). Frias et. al. (1991) observaram que em brotações no estádio F-2 (folhas maiores que $1,5 \mathrm{~cm}$ de comprimento) há pronunciada diminuição na orientação do tubo germinativo dos basidiósporos, quando comparada com brotações mais jovens. Por outro lado, infecção de gemas dormentes já foi obtida com sucesso (Bastos, 1994). O período suscetibilidade em frutos é de aproximadamente 100 dias (Andebrhan, 1981 e 1985b).

Não foi possível determinar neste experimento a distância máxima de disseminação do patógeno. Outros experimentos com distâncias maiores da fonte de inóculo devem ser realizados, além de trabalhos de inoculação de gemas dormentes, brotações em vários estádios e frutos, objetivando esclarecer o período de suscetibilidade dos tecidos em genótipos resistentes.

\subsection{Curvas de progresso da doença}

As curvas de progresso da doença quantificadas em vassouras vegetativas (Figura 12) evidenciaram um menor progresso no tratamento 3 . A proporção de doença obtida, nesse tratamento, no final do período analisado foi cerca de $25 \%$ do atingido no tratamento 1.

O mesmo ocorreu quando a doença foi quantificada em frutos (Figura 13). No tratamento 3, a proporção de doença no final do período foi cerca de $23 \%$ do obtido no tratamento 2 . As curvas dos tratamentos 2 e 1 foram semelhantes, embora a do tratamento 2 tenha sido superior que a do tratamento 1. 


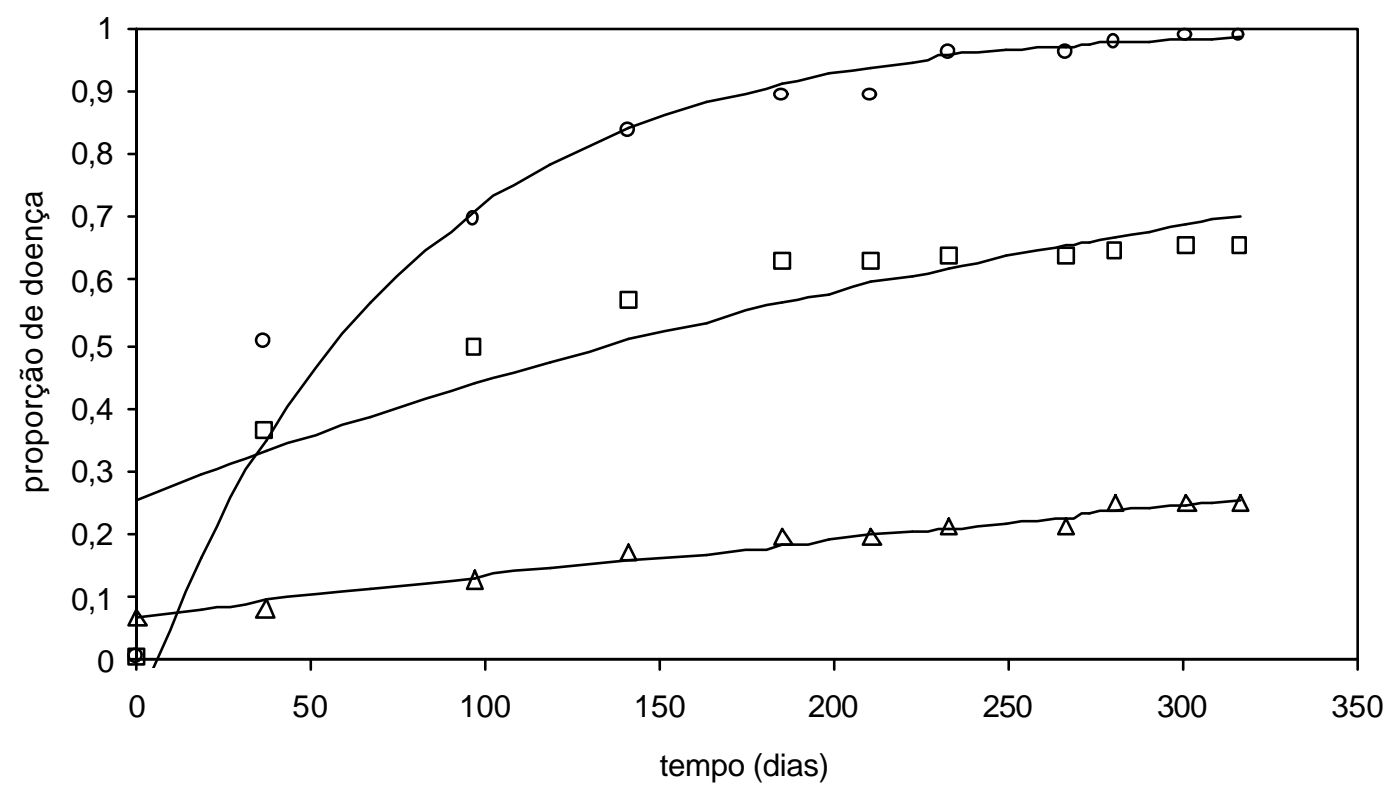

Figura 12 - Curvas de progresso da vassoura-de-bruxa do cacaueiro quantificada em vassouras vegetativas, nos tratamentos 1 (círculos vazios), 2 (quadrados) e 3 (triângulos). Ajuste epidemiológico (linha contínua). $(0=11 / 09 / 01)$.

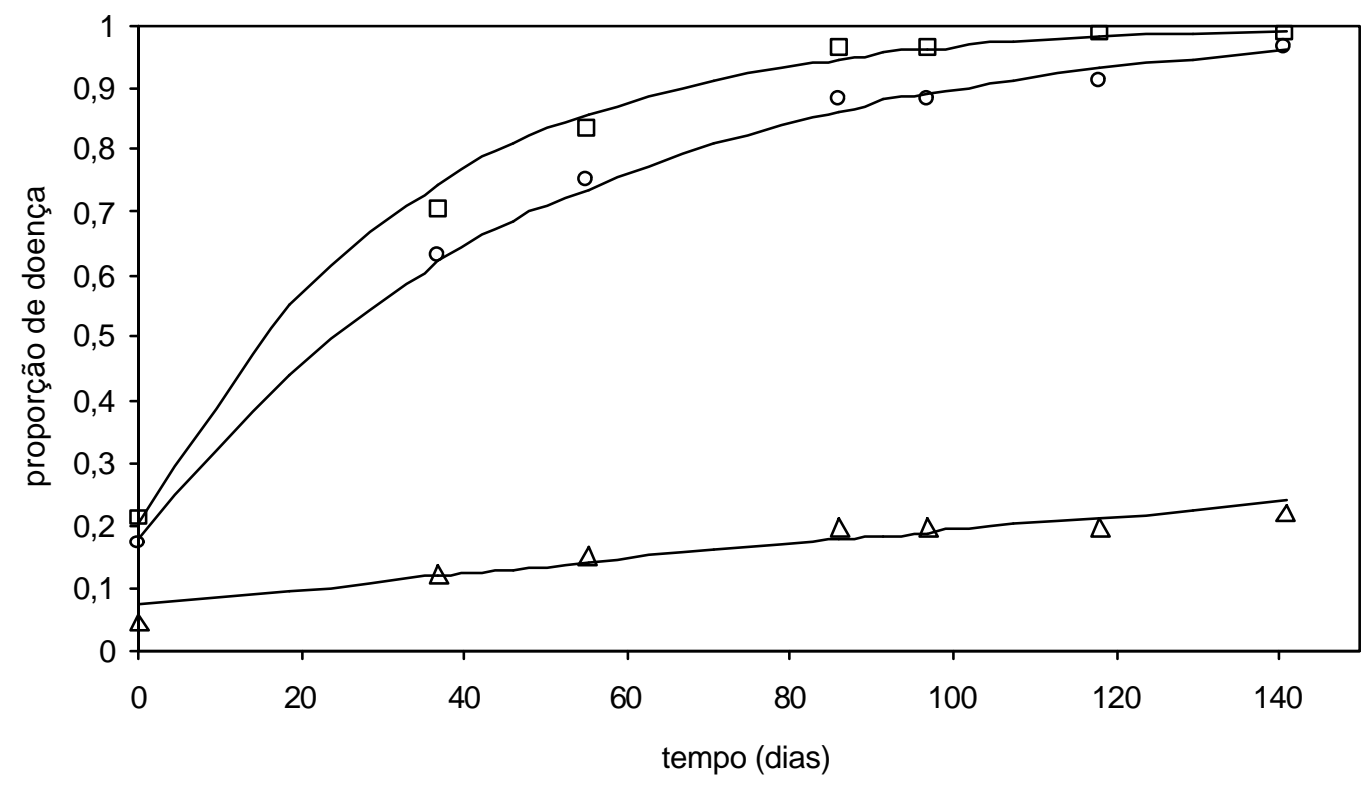

Figura 13- Curvas de progresso da vassoura-de-bruxa do cacaueiro quantificada em frutos com vassoura, nos tratamentos 1 (círculos vazios), 2 (quadrados) e 3 (triângulos). Ajuste epidemiológico (linha contínua). $(0=11 / 09 / 01)$ 
Houve bom ajuste dos dados de vassouras em ramos ao modelo monomolecular (Tabela 13). O tratamento 3 apresentou menores taxas de progresso da doença, tanto em ramos como em frutos.

Andebrhan (1985b), ao avaliar o progresso da vassoura-de-bruxa em três localidades da Amazônia, verificou que uma única poda fitossanitária na estação seca do ano não impediu que novas infecções continuassem a aparecer.

O ritmo de crescimento do cacaueiro é dependente do genótipo, condição edafo-climática e manejo (Andebrhan \& Almeida, 1985b). Mas, na Bahia, normalmente o maior pico de lançamento foliar ocorre entre setembro e novembro (Alvim, 1977 e Carzola et al., 1989). No presente trabalho, maior número de sintomas em ramos foi observado entre os meses de setembro e novembro (Figura 12).

Tabela 13. Taxas médias de progresso da vassoura-de-bruxa do cacaueiro $(r)$ em diferentes tratamentos

\begin{tabular}{cccc}
\hline Órgão & Tratamentos & $\mathrm{R}^{2}$ & Taxa (unidades/mês) \\
\hline Ramos & 1 & 0,961 & \\
& 2 & 0,837 & 0,405 \\
& 3 & 0,973 & 0,087 \\
Frutos & 1 & 0,021 \\
& 2 & 0,969 & \\
& 3 & 0,909 & 0,624 \\
& & & 0,936 \\
\end{tabular}

As taxas de infecção medidas em unidades por árvore, por mês, encontradas por Andebrhan (1985b) em Benevides, PA, nos anos de 1980 a 1982, foram de 0,76 a 0,96 para vassouras vegetativas, 0,71 a 0,87 para almofadas florais e 0,53 a 0,70 para frutos com vassoura.

Os valores obtidos no presente trabalho em vassouras vegetativas, nos tratamentos 1 e 2, foram menores que os obtidos em Benevides, PA. Essas menores taxas devem ter sido ocasionadas por 
diferenças na resistência dos materiais, ou pela maior freqüência na realização da poda.

As taxas de progresso da doença em frutos nos tratamentos 1 e 2 não apresentaram diferença daqueles obtidos em Benevides, PA. Indicando que as resistências dos materiais são semelhantes para esse órgão.

Embora tenham sido realizadas apenas duas remoções por ano na sub-área 1, não foi observada a produção de basidiocarpos nas vassouras na ocasião da remoção, sendo, portanto, atribuídas as infecções em frutos e ramos a inóculo vindo de fora da área.

\subsection{Comparação de métodos de controle e de genótipos}

\subsubsection{Em ramos}

Não foi possível realizar a análise de variância e nem mesmo a de deviance æ̀ contagens de vassouras vegetativas, pois muitas plantas não desenvolveram a doença nesse órgão, o que resultou em alta freqüência de zeros nos dados. As médias de vassouras vegetativas foram baixas em todos os genótipos, quando comparado com plantas suscetíveis (Tabela 14).

De forma geral, houve maior incidência da doença no tratamento 1 e uma tendência de médias menores no tratamento 3. Os genótipos que apresentaram menores médias nos tratamentos 1, 2 e 3 foram NO-13, NO-34 e NO-02, respectivamente. Os genótipos NO-12, NO-50 e NO-12 foram os que mostraram incidências maiores nos tratamentos 1,2 e 3, respectivamente.

Dentre as médias ponderadas dos genótipos, pode-se observar que os genótipos NO-34, NO-13 e NO-02 foram os que apresentaram os valores mais baixos, ficando abaixo da média geral. O genótipo NO-12 foi o único a ter mais de uma vassoura/planta/ano.

A média geral, na área experimental foi de 0,61 vassouras/planta/ano. Essa incidência é bastante baixa quando comparada 
com resultados obtidos por outros experimentos de comparação de métodos de controle.

Tabela 14. Médias de vassouras vegetativas quantificadas na safra global.

\begin{tabular}{ccccc}
\hline \multirow{2}{*}{ Genótipos } & \multicolumn{3}{c}{ Tratamentos } & \multirow{2}{*}{ Médias $^{1}$} \\
\cline { 2 - 4 } NO-02 & 1 & 2 & 3 & 0,33 \\
NO-10 & 0,25 & 0,86 & 0,00 & 0,48 \\
NO-12 & 0,89 & 0,50 & 0,24 & 1,59 \\
NO-13 & 1,88 & 0,92 & 1,00 & 0,33 \\
NO-17 & 0,17 & 0,50 & 0,25 & 0,48 \\
NO-24 & 0,90 & 0,41 & 0,14 & 0,87 \\
NO-34 & 1,09 & 0,94 & 0,21 & 0,29 \\
NO-42 & 0,44 & 0,23 & 0,09 & 0,47 \\
NO-50 & 0,81 & 0,36 & 0,18 & 0,97 \\
NO-52 & 1,08 & 1,54 & 0,10 & 0,86 \\
\hline Médias & 1,50 & 0,83 & 0,43 & 0,61 \\
${ }^{1}$ média ponderada dos genótipos & 0,57 & 0,21 & \\
${ }^{2}$ média ponderada dos tratamentos & &
\end{tabular}

Almeida et al. (1998) avaliaram o efeito da remoção e dessa associada a intervalos e dosagens de óxido cuproso no controle da vassourade-bruxa, obtendo resultados positivos na redução da incidência em ramos apenas em uma de quatro avaliações. A incidência da doença nesse órgão variou de 19,0 a 62,0 vassouras/planta/ano.

Costa \& Matuo (1999) testaram vários níveis do fungicida óxido cuproso no controle da doença em ramos, obtendo variações de 50,4 (na dosagem de $3,00 \mathrm{~g}$ do i.a./planta) a 87,1 (no tratamento sem aplicação do fungicida) vassouras/planta/ano, em dois anos de avaliação. Embora tenha havido essa variação, as médias não diferiram estatisticamente.

Os resultados do presente trabalho, embora não tenha sido possível realizar a análise estatística dos dados, indicaram que houve uma diminuição da incidência da doença em ramos pela aplicação do fungicida. 


\subsubsection{Em frutos}

A análise inicial revelou que a interação entre tratamentos e genótipos não foi significativa. A Tabela 15 apresenta os resultados da análise de deviance sem a interação de tratamentos e genótipos. Houve diferença significativa entre tratamentos (Tabela 16) e entre genótipos (Tabela 17).

Tabela 15. Análise de Deviance de frutos com vassoura computados na safra global.

\begin{tabular}{lccc}
\hline Fontes de variação & Graus de liberdade & Deviance & $\mathrm{F}$ \\
\hline Tratamentos & 2 & 18,59 & $9,30^{* *}$ \\
Genótipos & 9 & 71,08 & $7,90^{* *}$ \\
Resíduo & 505 & 488,19 & \\
\hline Valores de F seguidos por dois asteriscos & representam limites de confiança \\
acima de 99\%.
\end{tabular}

Tabela 16. Porcentagem de frutos com vassoura (\%FV) em três tratamentos. Tratamento 1 (poda semestral), Tratamento 2 (poda mensal), tratamento 3 (poda e aplicação de fungicida mensais).

\begin{tabular}{ll}
\hline Tratamentos & $\% \mathrm{FV}$ \\
\hline Tratamento 3 & $13,15 \mathrm{a}$ \\
Tratamento 2 & $18,55 \mathrm{~b}$ \\
Tratamento 1 & $19,08 \mathrm{~b}$ \\
\hline
\end{tabular}

Médias seguidas por pelo menos uma mesma letra, não diferem pelo teste de Wald a $5 \%$ de probabilidade.

O tratamento 3 (poda e aplicação de fungicida mensais) foi o que proporcionou menor percentual de frutos com vassoura, diferindo significativamente dos tratamentos 1 e 2 .

Não houve diferença entre os tratamentos de poda semestral (1) e poda mensal (2); esse resultado indica que não ocorreu aumento do inóculo dentro da área. Isso pode ter ocorrido devido à resistência dos genótipos e/ou por condições ambientais, pois o ciclo do patógeno é variável com as condições climáticas. 
Segundo Bartley (1977), a realização mais freqüente da poda poderia aumentar a indução da brotação da planta e resultar no aumento na incidência da doença. Esse fenômeno não foi observado nos genótipos testados, como pode ser observado na comparação dos tratamentos 1 e 2.

Considerando que o custo da poda é função, dentre outros fatores, da incidência da doença (Rudgard \& Andebrhan, 1987), as baixas incidências encontradas nos ramos das plantas do presente trabalho permitiriam que as podas fossem realizadas com freqüência trimestral ou até mesmo maiores, o que garantiria a quebra do ciclo do patógeno na área. Luz et al. (1997) recomendam podas trimestrais para as condições da Bahia.

Tabela 17. Comparação das médias de percentual de frutos com vassoura (\%FV) em dez genótipos.

\begin{tabular}{cc}
\hline Genótipos & $\% \mathrm{FV}$ \\
\hline NO-34 & $10,42 \mathrm{a}$ \\
NO-17 & $11,40 \mathrm{a}$ \\
NO-02 & $12,50 \mathrm{a}$ \\
NO-10 & $14,10 \mathrm{ab}$ \\
NO-50 & $9,95 \mathrm{a} \mathrm{b} \mathrm{c}$ \\
NO-52 & $17,36 \mathrm{a} \mathrm{b} \mathrm{c}$ \\
NO-12 & $20,96 \mathrm{~b}$ c \\
NO-42 & $22,39 \quad \mathrm{c} \mathrm{d} \mathrm{e}$ \\
NO-24 & $25,98 \quad$ ef \\
NO-13 & $36,54 \quad \mathrm{f}$ \\
\hline
\end{tabular}

Médias seguidas por pelo menos uma mesma letra, não diferem pelo teste de Wald a $5 \%$ de probabilidade.

Os genótipos NO-34, NO-17 e NO-02 foram os que apresentaram menores percentagens de frutos com vassoura, não diferindo estatisticamente dos genótipos NO-10, NO-50 e NO-52. Esses e o genótipo NO-12 foram significativamente diferentes dos genótipos NO-24 e NO-13.

Sgrillo et al. (1995) propuseram uma categorização de áreas afetadas com a vassoura-de-bruxa: Grau 1 - até início de infecção em frutos; Grau 2 - até cerca de 10\% de infecção em frutos; Grau 3A - até cerca de 50\% 
de frutos infectados e Grau 3B - mais de 50\% de frutos infectados. Desenvolveram também, um método de amostragem, que foi possível correlacionar a porcentagem de árvores infectadas, com níveis de infecção nos vários órgãos da planta. Rudgard \& Butler (1987) propuseram um modelo baseado na retirada de vassouras vegetativas para prever a porcentagem de frutos infectados.

Neste trabalho, o genótipo NO-13 foi o que apresentou maior percentual de frutos doentes. Por outro lado, na œmparação das contagens de vassouras vegetativas (item 4.3.1), esse genótipo apresentou bom nível de resistência. Assim fica constatado nesse genótipo que os níveis de resistência nos ramos e nos frutos não estão correlacionados. Esses resultados confirmam as observações realizadas por Bartley (1977) e Maddison et al. (1993a). Não foi possível categorizar a área deste estudo, devido à falta de correlação entre os órgãos. Essa diferença de reação à doença nos diferentes órgãos explica as diferenças obtidas nas análises de gradiente da doença.

Em experimento realizado em condições de campo por Costa \& Matuo (1999), foram obtidos 26,67 a $32,68 \%$ de frutos com vassoura no tratamento com $3 \mathrm{~g}$ do fungicida e 74,98 a $79,33 \%$ de frutos com vassoura na testemunha sem a aplicação do fungicida. Silva et al. (1985) testaram vários fungicidas em condição de campo e obtiveram porcentagem de frutos com vassoura entre $30,66 \%$ (no tratamento com calda bordalesa) e $72,12 \%$ de frutos com vassoura (no tratamento testemunha). As diferenças foram significativas entre tratamentos.

Os resultados do presente trabalho corroboram os obtidos por Almeida et al. (1998), pois houve diminuição significativa da porcentagem de frutos com vassoura, no tratamento em que foram combinadas a poda fitossanitária e a aplicação de fungicidas. 


\section{CONCLUSÕES}

A ausência de evidência clara da existência de gradiente de doença neste trabalho indica que basidióporos do patógeno estão disseminados por toda a região. Esse fato indica que programas fitossanitários implementados em áreas isoladas têm pouca chance de sucesso.

Os níveis de resistência genética à vassoura-de-bruxa de ramos e frutos não estão correlacionados entre si. Assim, testes nos frutos devem ser rotineiros nos programas de melhoramento.

O tratamento que combinou poda e pulverização com fungicida apresentou diferença significativa na redução do percentual de frutos com vassoura. Essa prática é viável desde que o material genético plantado tenha alto nível de resistência e baixo nível de infecção. 


\section{REFERÊNCIAS BIBLIOGRÁFICAS}

ALMEIDA, L.C.; ANDEBRHAN, T. Recuperação de plantações de cacau com alta incidência de vassoura-de-bruxa na Amazônia brasileira. In: CONFERÊNCIA INTERNATIONAL DE PESQUISAS EM CACAU, 10., Santo Domingo, 1987. Proceedings, Lagos: Cocoa Producers Alliance, 1987. p.337-339.

ALMEIDA, L.C.C.; NIELLA, G.R.; BEZERRA, J.L. Efeito de remoções de partes doentes do cacaueiro associadas a intervalos de aplicação de óxido cuproso no controle da vassoura-de-bruxa na Bahia. Agrotrópica, v.10, n.2, p.95102, 1998.

AMORIM, L. Disseminação. In: BERGAMIN FILHO, A.; KIMATI, H.; AMORIM, L. Manual de fitopatologia: princípios e conceitos. 3.ed. São Paulo: Ceres, 1995. cap.14, p.268-294.

ANDEBRHAN, T. Relação entre a idade do fruto do cacaueiro e suscetibilidade a Crinipellis perniciosa. Belém: CEPLAC/CEPEC, 1981. p.315-317. (Informe Técnico, 1981)

ANDEBRHAN, T. Epidemiologia da vassoura-de-bruxa. Belém: CEPLAC/CEPEC, 1982. p.314-321. (Informe Técnico, 1982)

ANDEBRHAN, T. Produção de basidiocarpos em vassouras de diferentes épocas do ano. Belém: CEPLAC/DEPEA, 1985a. p.45. (Informe de Pesquisas, 1985) 
ANDEBRHAN, T. Studies on the epidemiology and control of witches' broom disease of cacao in the Brazilian Amazon. In: INTERNATIONAL COCOA RESEARCH CONFERENCE, 9., Lome, 1985b. Proceedings, Lagos: Cocoa Producers Alliance, 1985. p.395-402.

ANDEBRHAN, T. Rain water as a factor in the dissemination of basidiospores of Crinipellis perniciosa (Stahel) Singer within cacao trees. In INTERNATIONAL COCOA RESEARCH CONFERENCE, 10., Santo Domingo. 1987. Proceedings, Lagos: Cocoa Producers Alliance, 1987. p.367-369.

ANDEBRHAN, T.; ALMEIDA, L.C. Aspectos epidemiológicos da resistência de híbridos a vassoura-de-bruxa. Belém: CEPLAC/DEPEA, 1985a. p.60. (Informe de Pesquisas, 1985)

ANDEBRHAN, T.; ALMEIDA, L.C. Aspectos fenológicos da resistência do cacaueiro a C. perniciosa. Belém: CEPLAC/DEPEA, 1985b. p.61-62. (Informe de Pesquisas, 1985)

ANDEBRHAN, T.; ALMEIDA, L.C. de; NAKAYAMA, L.H.I. Resistência de Theobroma cacao L. A Crinipellis perniciosa (Stahel) Singer: A experiência da Amazônia brasileira. Agrotrópica, v.10, n.2, p.49-60, 1998.

ANDEBRHAN, T.; MADDISON, A.C.; ARIAS, R.; MAFFIA, L.A. Disease gradients of Crinipellis perniciosa on cocoa seedlings. In: RUDGARD, S.A.; MADDISON, A.C.; ANDEBRHAN, T. (Ed.). Disease Management in cocoa: comparative epidemiology of witches' broom. London: Chapman \& Hall, 1993. cap.12, p.157-164.

ALVIM, P.T. Cacao. In: ALVIM, P.T.; KOZLOWSKI, T. T. (Ed.). Ecophysiology of Tropical Crops. New York: Academic, 1977. cap.10, p.279-313.

ARAGUNDI, J.; FRIAS, G.; SOLORZANO, G.; SCHIMIDT, R.; PURDY, L.H. Estudios sobre gradiente de infeccion y dispersion de la escoba de bruja del 
cacao en el Ecuador. In: CONFERENCIA INTERNACIONAL DE INVESTIGACIÓN EN CACAO, 10., Santo Domingo. 1987. Proceedings, Lagos: Cocoa Producers Alliance, 1987. p.375-379.

BAKER, R.E.D.; CROWDY, S.H. Studies in the witches' broom disease of cocoa caused by Marasmius perniciosus Stahel.: Introduction, symptons and etiology. Port-of-Spain: ICTA, 1943. 28p. (Memoir 7)

BAKER, R.E.D.; CROWDY, S.H.; THOROLD, C.A. Witches' broom disease investigations. I. Seasonal variations in the intensity of infections and their effect on control measures. Tropical Agriculture Trinidad, v.18, p.107-116, 1941.

BARTLEY, B.G.D. The status of genetic resistence in cocoa to Crinipellis perniciosa (Stahel) Singer. In: INTERNATIONAL COCOA RESEARCH CONFERENCE, 6., Caracas, 1977. Proceedings, Lagos: Cocoa Producers Alliance, 1977. 18p.

BASTOS, C.N. Capacidade de Crinipellis perniciosa produzir basidiósporos viáveis em vassouras com três anos de idade e de infectar tecidos do cacaueiro com gemas dormentes. Fitopatologia Brasileira, v.19, n.4, p.585$587,1994$.

BASTOS, E. Cacau: a riqueza agrícola da América. São Paulo: Ícone, 1987. 130p.

BERGAMIN FILHO, A. Curvas de progresso da doença. In: BERGAMIN FILHO, A.; KIMATI, H.; AMORIM, L. Manual de fitopatologia: princípios e conceitos. 3.ed. São Paulo: Ceres, 1995. cap. 30, p.602-626.

BERGAMIN FILHO, A.; HAU, B.; AMORIM, L.; LARANJEIRA, F.F. Análise espacial de epidemias. Revisão Anual de Patologia de Plantas, v.10, p.155-218, 2002. 
CARZOLA, I. M.; AIDAR, I.; MILDE, L. C. E. Perfis do lançamento foliar, da floração, da bilração e de estágios do fruto do cacaueiro no Estado da Bahia, no período 1977/88. Ilhéus: CEPLAC. 1989. 58p.

CIFUENTES, C.; MAYORGA, M.; PRIETO, E.; RONDON, G.; TOVAR, G. Estudio cuantitativo de la produccion de escobas en plantas de cacao, afectadas por Crinipellis perniciosa (Stahel) Singer y su significado en el manejo de la enfermidad. In: CONFERENCIA INTERNACIONAL DE INVESTIGACIÓN EN CACAO, 8., Cartagena, Colombia, 1982. Proceedings, Lagos: Cocoa Producers Alliance, 1982. p.407-413.

COMPANHIA DAS DOCAS DO ESTADO DA BAHIA, 2002. Apresenta, em estatísticas, os principais produtos movimentados. <http://www.codeba.com.br/portoilheus>. (15 nov. 2002)

COSTA, A.Z. de M.; MATUO, T. Determinação de níveis de fungicida óxido cuproso em frutos de cacaueiros para o controle da vassoura-de-bruxa. Agrotrópica, v.11, n.2, p.77-82, 1999.

COSTA, J.C. do B. Progresso da vassoura-de-bruxa em órgãos vegetativos do cacaueiro em Altamira e Tomé-Açu, Pa. Viçosa, 1993. 52p. Dissertação Mestrado - Universidade Federal de Viçosa.

EVANS, H.C.; BASTOS, C.N. Uma reavaliação do ciclo da vida da vassoura-debruxa (Crinipellis perniciosa) do cacau. Fitopatologia Brasileira, v.4, n.1, p.104, 1979.

EVANS, H.C.; SOLORZANO, G.R. Witches' broom disease: wrong experiment rigth results. In: INTERNATIONAL COCOA RESEARCH CONFERENCE, 8., Cartagena, Colombia, 1982. Proceedings, Lagos: Cocoa Producers Alliance, 1982. p.415-418.

FAO. Prodution Yearbook, v.54, 2000. Rome, 2002. 260p. 
FRIAS, G.A.; PURDY, L.H.; SCHIMIDT, R.A. Infection biology of Crinipellis perniciosa on vegetative flushes of cacao. Plant Disease, v.75, n.6, p.552556, 1991.

GREGORY, P.H. Microbiology of the atmosphere. 2.ed. Plymouth: Leonard Hill, 1973. 377p.

HOLLIDAY, P. Witches' broom disease of cacao Marasmius perniciosus Stahel). London: Her Majesty's stationery office, 1952. 8p.

LUZ, E. D. M. N.; BEZERRA, J. L.; OLIVEIRA, M. L.; RESENDE, M. L. V. Doenças do cacaueiro. In ZAMBOLIM, L. e VALE, F.X.R. (Ed.). Controle de doenças de plantas: grandes culturas. Viçosa: UFV. Imprensa Universitária, 1997. cap.13, p.611-655.

McCULLAGH, P.; NELDER, J. A. Generalized Linear Models. 2.ed. London: Chapman and Hall, 1989. 511p.

MADDISON, A.C.; ANDEBRHAN, T.; ARANZAZU, F.; SILVA-ACUÑA, R. Comparative phytosanitation studies. In: RUDGARD, S.A.; MADDISON, A.C.; ANDEBRHAN, T. (Ed.). Disease Management in cocoa: comparative epidemiology of witches' broom. London: Chapman \& Hall, 1993a. cap.13, p.165-188.

MADDISON, A.C.; MACIAS, G.; MOREIRA, C.; ARAGUNDI, J. Comparative epidemiology study: Equador. In: RUDGARD, S.A.; MADDISON, A.C.; ANDEBRHAN, T. (Ed.). Disease Management in cocoa: comparative epidemiology of witches' broom. London: Chapman \& Hall, 1993b. cap.7, p.73-92.

NELDER, J. A.; WEDDERBURN, R. W. M. Generalized Linear Models. Journal of the Royal Statistical Society A, v.135, n.3, p. 370-384, 1972. 
NIELLA, G. R. Esporulação de Crinipellis perniciosa (Stahel) Singer em frutos de cacau (Theobroma cacao L.) no sudeste da Bahia e sensibilidade "in vitro" a quatro compostos sulfurados. Lavras, 1997. 60p. Dissertação Mestrado Universidade Federal de Lavras.

PEREIRA, J. L.; RAM, A.; FIGUEIREDO, J. M. de; ALMEIDA, L. C. C. de. First occurence of witches' broom disease en the principal cooca-growing region of Brasil. Tropical Agriculture, v.67, n.2, p.188-189, 1990.

PURDY, L.H.; SCHMIDT, R.A. Status of cacao witches' broom: biology, epidemiology, and management. Annual Review of Phytopathology, v.34, p.573-594, 1996.

ROCHA, H.M.; WHEELER, B.E.J. Factors influencing the production of basidiocarps and the deposition and germination of basidiospores of Crinipellis perniciosa, the causal fungus of witches' broom on cocoa (Theobroma cacao). Plant Pathology, v.34, p.319-328, 1985.

ROSA, I. de S. Enxertia do cacaueiro. Ilhéus: CEPLAC/SUBES/CEPEC, 1998. $42 p$.

RUDGARD, S.A. Interpreting the epidemiology of cocoa witches' broom for better disease management in Rondonia, Brazil. Cocoa Growers' Bulletin, n.38, p.28-38, 1987a.

RUDGARD, S.A. Witches' broom disease of cocoa in Rondonia, Brazil: infection of vegetative flushes and flower cushions in relation to host phenology. Plant Pathology, v.36, p.523-530, 1987b.

RUDGARD, S.A.; ANDEBRHAN, T. Predicting the cost-benefits of sanitation pruning for the management of witches' broom disease. In: INTERNATIONAL COCOA RESEARCH CONFERENCE, 10., Santo Domingo. 1987. Proceedings, Lagos: Cocoa Producers Alliance, 1987. p.341-344. 
RUDGARD, S.A.; BUTLER, D.R. Witches' broom disease of cocoa in Rondonia, Brazil: pod infection in relation to pod susceptibility, wetness, inoculum, and phytosanitation. Plant Pathology, v.36, p.515-522, 1987.

SANTOS FILHO, L.P. dos; FREIRE, E.S.; CARZOLA, I.M. Estimativas de perdas de produção de cacau causadas por vassoura-de-bruxa (Crinipellis perniciosa (Stahel) Singer) na Bahia. Agrotrópica, v.10, n.3 , p.127-130, 1998.

SAS Institute. SAS/STAT User's Guide 8.0. Cary, N. C.: SAS Institute Inc., 1999.

SGRILLO, R.B.; LUZ, E.D.M.N.; ARAÚJO, K.R.P. de. Método de amostragem seqüencial para avaliação do nível de infecção em áreas de cacau afetadas pela vassoura-de-bruxa na Bahia. Agrotrópica, v.7, n.2, p.31-42, 1995.

SILVA, J.A.; RODRIGUES, C.H.; ALMEIDA, L.C.; ANDEBRHAN, T. Efeito de fungicidas no controle da vassoura-de-bruxa do cacaueiro em condições de campo. Belém: CEPLAC/DEPEA, 1985. p.48-51. (Informe de Pesquisas, 1985)

SILVA, P.; CARDOSO, A. de O. Histórico das introduções de cacaueiro (Theobroma cacao L.) no recôncavo da Bahia, Brasil. Revista Theobroma, v.10, n.3, p.135-140. 1980.

SILVA, S.D.V.M.; MATSUOKA, K. Histologia da interação Crinipellis perniciosa em cacaueiros suscetível e resistente à vassoura-de-bruxa. Fitopatologia Brasileira, v.24, n.1, p.54-59. 1999.

SOBERANIS, W.; RÍOS, R.; ARÉVALO, E.; ZÚÑIGA, L.; CABEZAS, O.; KRAUSS, U. Increased frequency of phytosanitary pod removal in cocoa (Theobroma cacao) increases yield economically in eastern Peru. Crop Protection, v.18, p.677-685. 1999. 
SREENIVASAN, T.N.; DABYDEEN, S. Modes of penetration of young cocoa leaves by Crinipellis perniciosa. Plant Disease, v.73, p. 478-481, 1989.

TOLLENAAR, C.A. Increase cocoa production by foliar copper applications as an effect addicional to witches'broom disease control. Tropical Agriculture, v.36, n.3, p.177-188, 1959.

TOVAR, R.G. La escoba de bruja del cacao (Crinipellis perniciosa (Stahel) Singer) en el piedemonte llanero de Colombia: epidemiologia, resistência y manejo. Agronomia Colombiana, v.8, p.1-239, 1991.

TREVIZAN, S.D.P. Mudanças no sul da Bahia associadas a vassoura-de-bruxa do cacau. In: INTERNATIONAL COCOA RESEARCH CONFERENCE, 12, Salvador. 1996. Proceedings, Lagos: Cocoa Producers Alliance, 1996. p.1109-1116. 